\title{
Pendekatan Reggio Emilia dalam Menjawab Tantangan Kemampuan Anak Usia Dini Abad 21
}

\author{
Rini Julia Sasmita ${ }^{\circledR}$, Tuti Tarwiyah ${ }^{2}$, Tjipto Sumadi ${ }^{3}$ \\ Pendidikan Anak Usia Dini, Universitas Negeri Jakarta, Indonesia \\ DOI: $10.31004 /$ obsesi.v6i1.1217
}

\begin{abstract}
Abstrak
Pada abad ke-21 ini, setiap manusia termasuk anak usia dini menghadapi tantangan globalisasi. Berdasarkan penelitian terdahulu disimpulkan bahwa pembelajaran yang dapat mempersiapkan anak untuk memiliki kemampuan abad ke-21 adalah pendekatan yang berorientasi pada anak. Pendekatan Reggio Emilia adalah salah pendekatan yang berorientasi pada anak. Pendekatan ini menggunakan pembelajaran berbasis proyek dan menggunakan material terbuka yang telah teruji dapat mengembangkan kemampuan abad ke-21, namun Pendekatan ini memiliki komponen pembelajaran lain. Maka tujuan penelitian ini adalah ingin melihat apakah seluruh komponen Pendekatan ini mampu menjawab tantangan kemampuan di abad ke-21, dan apakah pendekatan dari kota Italia ini dapat diaplikasikan di dalam konteks pendidikan Indonesia. Penelitian ini menggunakan metode penelitian tinjauan pustaka, menganalisa 2 buku sumber data primer tentang Pendekatan Reggio Emilia, 1 buku sumber data primer tentang Pendidikan menurut Ki Hajar Dewantara dan 62 artikel yang terdiri dari sumber data primer dan sekunder tentang Pendekatan Reggio Emilia dan Kemampuan abad ke-21.
\end{abstract}

Kata kunci: reggio emilia; kemampuan abad ke-21; pendidikan anak usia dini

\begin{abstract}
In $21^{\text {st }}$ century, every people is facing the globalization challenges included young children.. Based on previous research, that abilities can prepared by child-orientated approach. Reggio Emilia Approach is one of that. Reggio Emilia using project based-learning and open ended material that have developed $21^{\text {st }}$ century skills. However, the Reggio EmiliaApproach has another component that may also potential to developed that abilities. The aim of this study is too see all the Reggio Emilia components are able to answer the challenges, and to see the probability to applied this approach in the Indonesian context. This study us a literature review research method, with analyzed 2 primary source books on the Reggio Emilia Approach, 1 primary book of Education according to Ki Hajar Dewantara and 62 articles consisting of primary and secondary sources about Reggio Emilia Approach and $21^{\text {st }}$ century skills.
\end{abstract}

Keywords: reggio emilia; $21^{\text {st }}$ century skills; early childhood education

Copyright (c) 2021 Sri Yunimar Ningsih, Nenny Mahyuddin

$\triangle$ Corresponding author:

Email Address: rinijuliasasmita87@gmail.com (Jakarta, Indonesia)

Received 26 March 2021, Accepted 8 April 2021, Published 14 April 2021 


\section{PENDAHULUAN}

Para peneliti terdahulu mengatakan bahwa di masa depan setiap pribadi harus memiliki kemampuan abad ke-21 agar dapat bertahan di masa depan. Dalam konteks anak usia dini kemampuan abad ke-21 ini adalah kreativitas, kolaborasi, kritis dalam berpikir, dan komunikasi (Kaufman, 2013) (Lindeman \& Anderson, 2015) (Zulkarnaen et al., 2018). Kemampuan abad 21 menjadikan anak dapat mengaplikasikan apa yang sudah dipelajarinya semasa sekolah pada kehidupan masa mendatang di dalam masyarakat yang penuh persaingan (Weber, 2019).

Pada nyatanya harapan agar anak memilik kemampuan bertahan di abad ke-21 dibebankan kepada pendidikan (sekolah) sebagai pihak yang bertanggungjawab. Hal tersebut memancing pertanyaan yaitu model pembelajaran seperti apakah yang dapat menjanjikan kemampuan abad 21 ini terpenuhi. Pertanyaan berikutnya adalah sejak usia berapa anak dapat dibekali dengan kemampuan abad ke-21. Apakah anak usia dini sudah siap untuk dibekali kemampuan abad ke-21. Beberapa penelitian menunjukan bahwa tidak perlu ada keraguan, karena kemampuan abad ke-21 dapat diberikan sejak anak usia dini (Weber, 2019) (Lindeman \& Anderson, 2015) (Kandari, 2020) (Kewalramani, 2020).

Terdapat dua model pendekatan pembelajaran yang terjadi di sekolah yaitu model pendekatan yang berpusat kepada guru dan model pendekatan yang berpusat pada anak (Hanafi, 2014). Model pendekatan yang berpusat pada guru adalah pendekatan yang menitikberatkan kegiatan pembelajaran kepada guru, menekankan pembelajaran akademik dan berfilosofi non-konstruktivis (Harris, 2018). Dalam model pendekatan ini peran guru sangat penting karena menjadi sumber, standar instruksi, standar moral, dan standar regulasi yang akan diterima oleh anak-anak.

Filosofi dibalik pendidikan model ini adalah meletakan guru sebagai sumber pengetahuan, siswa sebagai penerima pengetahuan dan model pendidikan ini mempengaruhi suasana pembelajaran yang pasif, karena terhabituasi untuk mendengar bukan berbicara dan untuk menerima pengetahuan bukan membagikan pengetahuan. Atmosfir dari model pembelajaran ini cenderung menjadikan siswa pasif dalam belajar, tidak termotivasi untuk aktif, berinisiatif, imajinatif, kreatif, berpikiran kritis, kemampuan analisa yang tumpul, tidak terbiasa berkolaborasi dan tidak berani mengungkapkan pendapat. Padahal karakter-karakter inilah yang merupakan cita-cita di dalam pendidikan abad ke-21.

Berbeda dengan pendidikan yang berpusat pada anak, berfilosfi dari pendekatan ini adalah konstruktivis, interaktif, dan pembelajarannya dengan basis bermain (Harris, 2018). Model pendekatan ini memperhatikan kebutuhan dan perkembangan anak, disebut sebagai pendidikan yang efektif dan berkualitas tinggi karena berkontribusi pada kesehatan mental anak, mempertimbangkan dan meletakan pendapat anak pada posisi penting, pendekatan ini juga menitikberatkan pada respon terhadap perkataan dan tindakan anak (Perren et al., 2017).

Dalam model pendekatan ini, anak menjadi lebih dimanusiakan, dilihat sebagai sebuah pribadi yang utuh, dan memiliki potensi yang sama besarnya dengan orang dewasa, yang didengar dan dihargai pendapatnya. Model pendekatan yang lebih disukai daripada model pendekatan yang berpusat pada guru ini dirintis oleh beberapa tokoh seperti Froebel, Rousseau, Montessori, Piaget, Vygotsky, Gardner, Dewey, dan Bruner (Harris, 2018) (Birinci, 2018) (Dodd-nufrio, 2011). Ki Hajar Dewantara, seorang tokoh pendidikan Indonesia yang dipengaruhi oleh Frobel dan Montessori juga mencetuskan "Tut Wuri Handayani" yang berarti memberikan kebebasan pada anak seluas-luasnya selama tidak ada ancaman yang membahayakan (Magta, 2013).

Pendidikan yang berpusat pada anak sudah terjadi di Eropa sekitar tahun 1900. Di Eropa bermunculan metode dan pendekatan yang berpusat pada anak seperti metode Montessori, Waldrof, dan Pendekatan Reggio Emilia yang kemudian menyebar luas ke berbagai negara. Reggio Emilia adalah suatu kota kecil di Italia yang kemudian pendekatan ini dinamai sesuai dengan nama kotanya. Pendekatan Reggio Emilia muncul dari kerinduan para orangtua untuk mendidik anak-anaknya pasca perang dunia kedua (Mitchiner et al., 
2018) (Mcnally \& Slutsky, 2016) (Cutcher, 2013) (Dodd-nufrio, 2011) (C. Edwards \& Gandini, 2012). Pendekatan ini yang dipimpin oleh seorang guru sekaligus psikolog bernama Loris Malaguzzi. Dia memiliki filosofi dan keunikan yang berbeda dengan metode atau pendekatan lainnya. Pendekatan Reggio Emilia berpotensi untuk megembangkan kemampuan yang diharapkan di abad ke-21.

Pendekatan Reggio Emilia memiliki slogan yang terkenal yaitu "Seratus Bahasa Anak" yang berarti bahwa anak terlahir dengan banyak cara, bahkan ratusan cara dalam mengkomunikasikan isi hati dan pikiran mereka. Di dalam proses pembelajaran, pendekatan ini juga menggunakan pembelajaran berbasis proyek yang dapat mengembangkan kemampuan berpikir kritis, kolaborasi dan komunikasi dengan guru maupun teman sebaya (Weber, 2019) (Bell, 2010). Materi atau media pembelajaran di dalam Pendekatan Reggio Emilia menggunakan material terbuka atau bisa disebut material lepasan. Material ini dapat mengembangkan komunikasi, interaksi, mendukung kolaborasi, koorperasi, juga mempromosikan kemampuan sosial karena mendukung kreasi dan inovasi (Daly \& Beloglovsky, 2019).

Berdasarkan urian di atas, Pendekatan Reggio Emilia memiliki kekuatan, daya tarik, dan keunikan di dalam pengaplikasiannya yang dapat membantu anak memperoleh kemampuan di abad ke-21. Maka penelitian ini mengambil kajian pustaka untuk melihat apa sajakah komponen pembelajaran dalam Pendekatan Reggio Emilia. Juga melihat apakah komponen pembelajaran dari Pendekatan Reggio Emilia mampu menjawab empat tantangan kemampuan anak usia dini di abad ke-21 dan di dalam konteks pendidikan Indonesia.

\section{METODOLOGI}

Penelitian dilakukan dengan metode tinjauan pustaka. Tinjauan pustaka memiliki kelebihan, metode ini bukanlah sebuah tulisan posisi, dalam arti peneliti hanya memilih data yang mendukung pandangannya saja (Efron \& Ravid, 2019), namun bukan juga berarti menyajikan semua data di lapangan secara gamblang. Menurut Boote \& Baile di dalam Efron \& Ravid (Efron \& Ravid, 2019) sebuah tinjauan pustaka seharusnya menyajikan sebuah perspektif segar dan kreatif yang memberikan kontribusi berpikir dan pemahaman terhadap topik yang sedang diteliti.

Instrumen dari penelitian tinjauan pustaka yaitu peneliti itu sendiri (Efron \& Ravid, 2019), untuk menjadi instrumen yang baik maka peneliti harus dengan teliti dan berhati-hati dalam memilih sumber data. Sebuah sumber data memuat banyak artikel penelitian, untuk menolong peneliti dalam memilih artikel yang baik dan menganalisa data sehingga tidak bias, maka diperlukan alat bantu berupa tabel seleksi. Peneliti dapat membatasi penelusurannya dengan menggunakan titik jenuh atau informasi yang diulang-ulang (Efron \& Ravid, 2019).

Panduan pengumpulan, pencatatan dan analisa data pada penelitian ini menggunakan panduan dari Efron dan Ravid. Adapun sumber data dalam penelitian ini adalah buku, artikel penelitian terdahulu yang sudah terpublikasi sehingga memiliki data yang dapat dipertanggungjawabkan. Setelah data dikumpulkan maka data dianalisa, direduksi, disajikan dan kemudian diverifikasi menggunakan tabel dan diagram. 


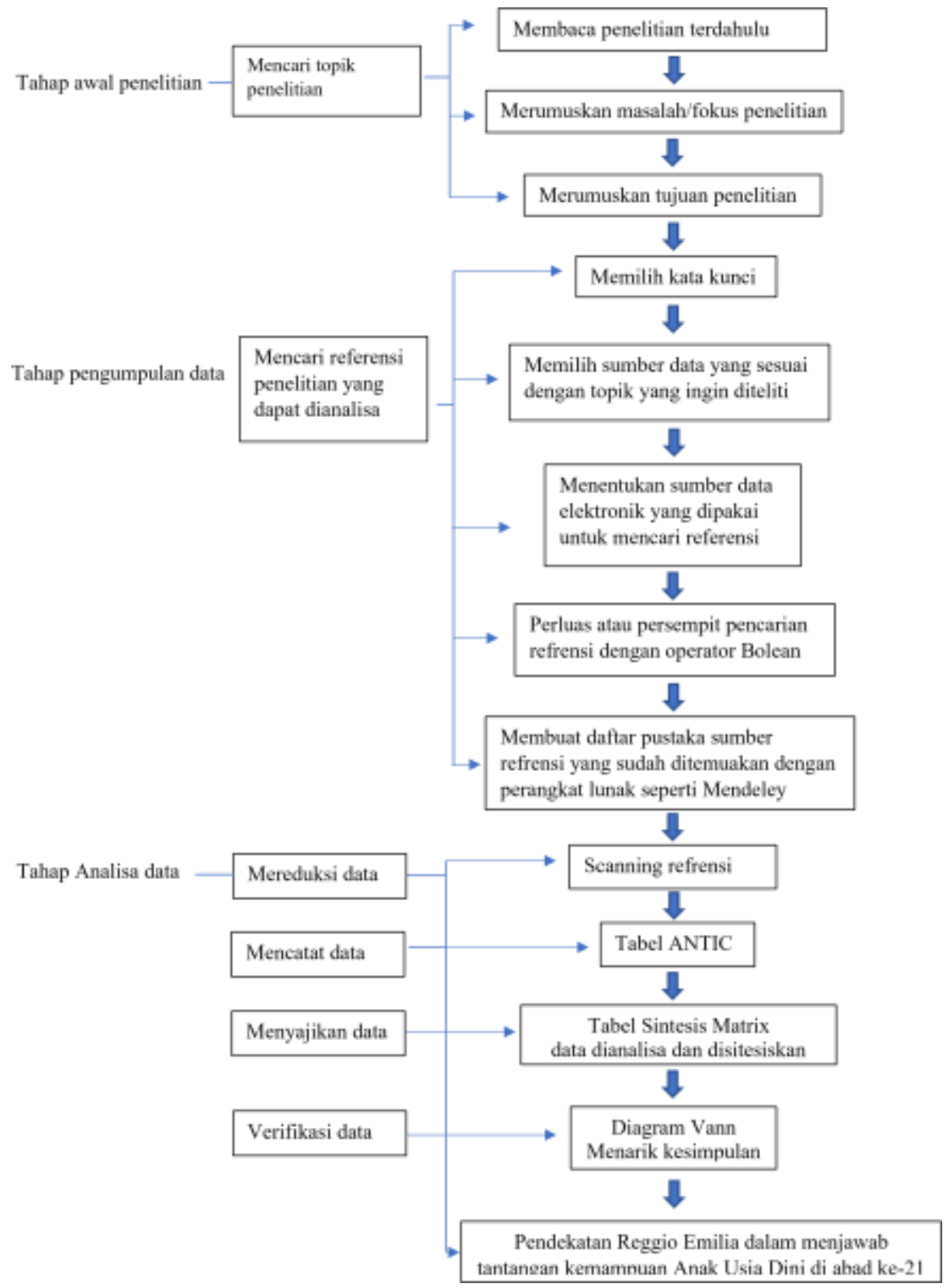

Gambar 1. Tahapan Penelitian

\section{HASIL DAN PEMBAHASAN}

Hasil penelitian ini diperoleh melalui studi kajian pustaka yang menganalisa 2 buku sumber data primer tentang Pendekatan Reggio Emilia, 1 buku sumber data primer tentang Pendidikan Ki Hajar Dewantara dan 62 artikel penelitian yang terdiri dari sumber data primer dan sekunder. Sumber data ini diperoleh baik melalui perpustakaan elektronik maupun fisik. Perpustakaan elektronik yang diakses adalah ERIC, Google Scholar dan Z-library, dengan bantuan berupa operator Bolean yang berguna untuk memperluas dan mempersempit pencarian.

Artikel penelitian yang digunakan dalam penelitian ini adalah artikel dengan jangka waktu sepuluh tahun terakhir. Namun diantaranya terdapat dua artikel yang diterbitkan tahun 2000, 2001, 2003 dan buku yang diterbitkan pada tahun 2008. Artikel dan buku ini tetap dianalisa dengan alasan keempat sumber ini adalah sumber data primer. Setelah data dikumpulkan dan direduksi, maka langkah berikutnya adalah pencatatan menggunakan tabel ANTIC, disajikan dengan tabel Sintesis Matrix, kemudian diverifikasi menggunakan Diagram Vann. 

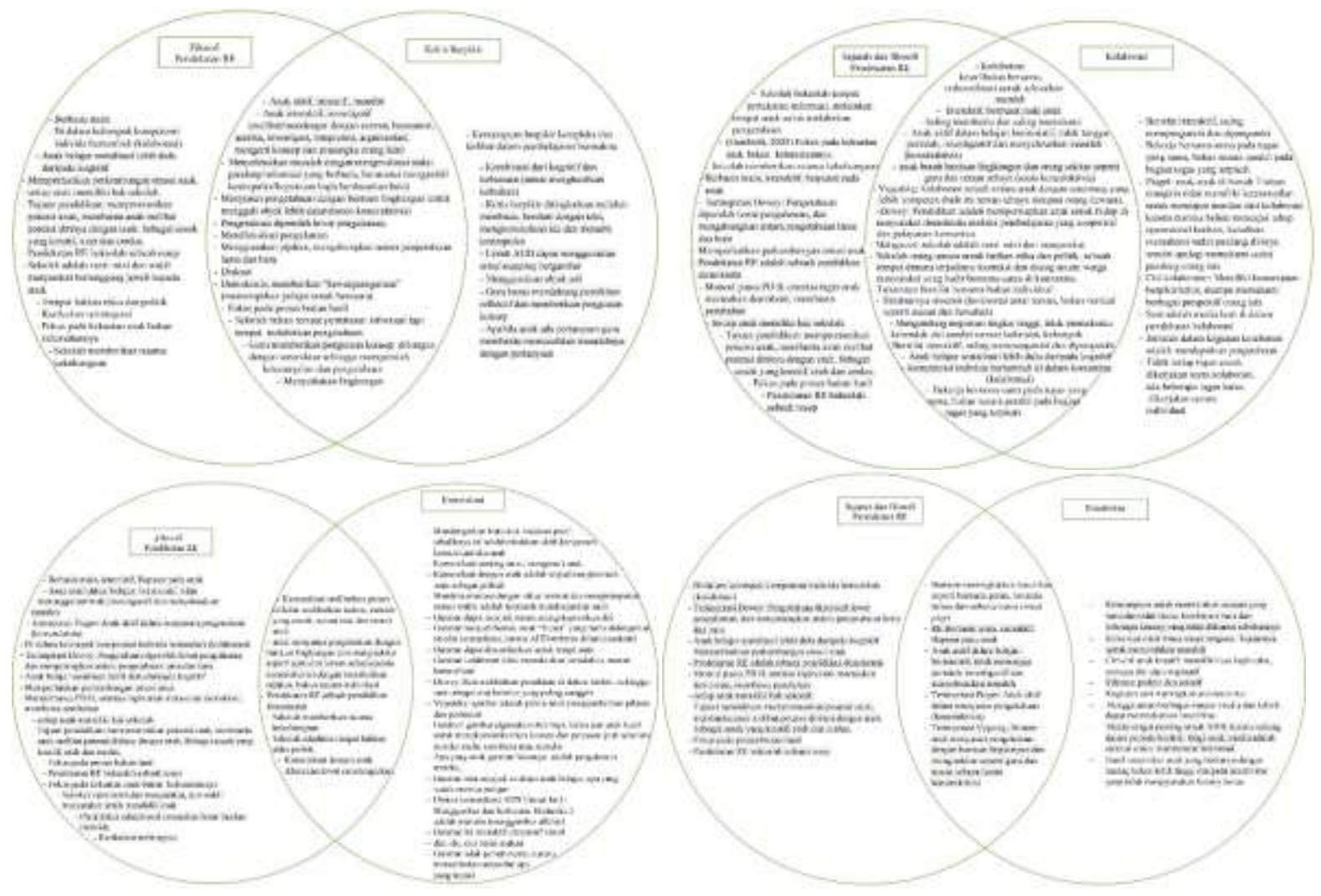

Gambar 2. Diagram Vann: “Filosofi Reggio Emilia dengan Kemampuan abad ke-21"

Filosofi Pendekatan Reggio Emilia dapat menjawab tantangan kemampuan abad ke-21

Pada gambar 2, dapat dilihat bahwa Filosofi pendekatan Reggio Emilia memiliki teori yang saling bersinggungan dengan teori dari empat kemampuan yang diharapkan ada pada anak di abad ke-21. Karena pendekatan ini berorientasi pada anak, anak adalah sosok aktif, sekolah sebagai pemberi "kewarganegaraan" yang demokratis pada anak, konsep belajar yang sosio konstruktivis, merefleksikan pengalaman, tidak sekedar menukar informasi, terfokus pada proses dan menyediakan lingkungan. Hal-hal ini mendukung anak dalam menganalisa, menginvestigasi, merefleksikan pengalaman, berdiskusi sehingga dapat berpikir dengan kompleks dan menyelesaikan masalah berdasarkan bukti, yang adalah elemen dari kritis berpikir. Pendekatan Reggio Emilia menggunakan bermain dalam pembelajarannya. Dan berdasarkan teori, kreativitas dapat dikembangkan lewat permainan.

Di dalam pendekatan ini, meskipun anak dilihat sebagai sosok yang mampu, mereka juga memerlukan bantuan lingkungan (baik material, guru atau teman sebaya) dalam menyusun pengetahuan. Konsep ini menggambarkan bahwa filosofi Pendekatan Reggio Emilia sesuai dengan konsep kolaborasi yaitu saling terlibat, saling membantu dan saling memahami demi tujuan bersama. Filosofi lainnya dari Pendekatan Reggio Emilia adalah anak belajar sosialisasi terlebih dahulu daripada kognitif. Saat berelasi dengan anak lain mereka saling membantu, saling memahami, dan ini sesuai dengan konsep kolaborasi.

Pendekatan ini memperlakukan anak secara domokratis, anak bebas berbicara dan didengarkan. Hal ini selaras dengan teori komunikasi, yaitu misalnya komunikasi melibatkan proses mendengarkan, proses refleksi, melibatkan indera, ramah anak dan sesuai usia. Pendekatan ini juga berfilosofikan sosio konstruktivis dalam pembelajaraannya yang melibatkan tindakan berkomunikasi dengan lingkungan sekitarnya. 

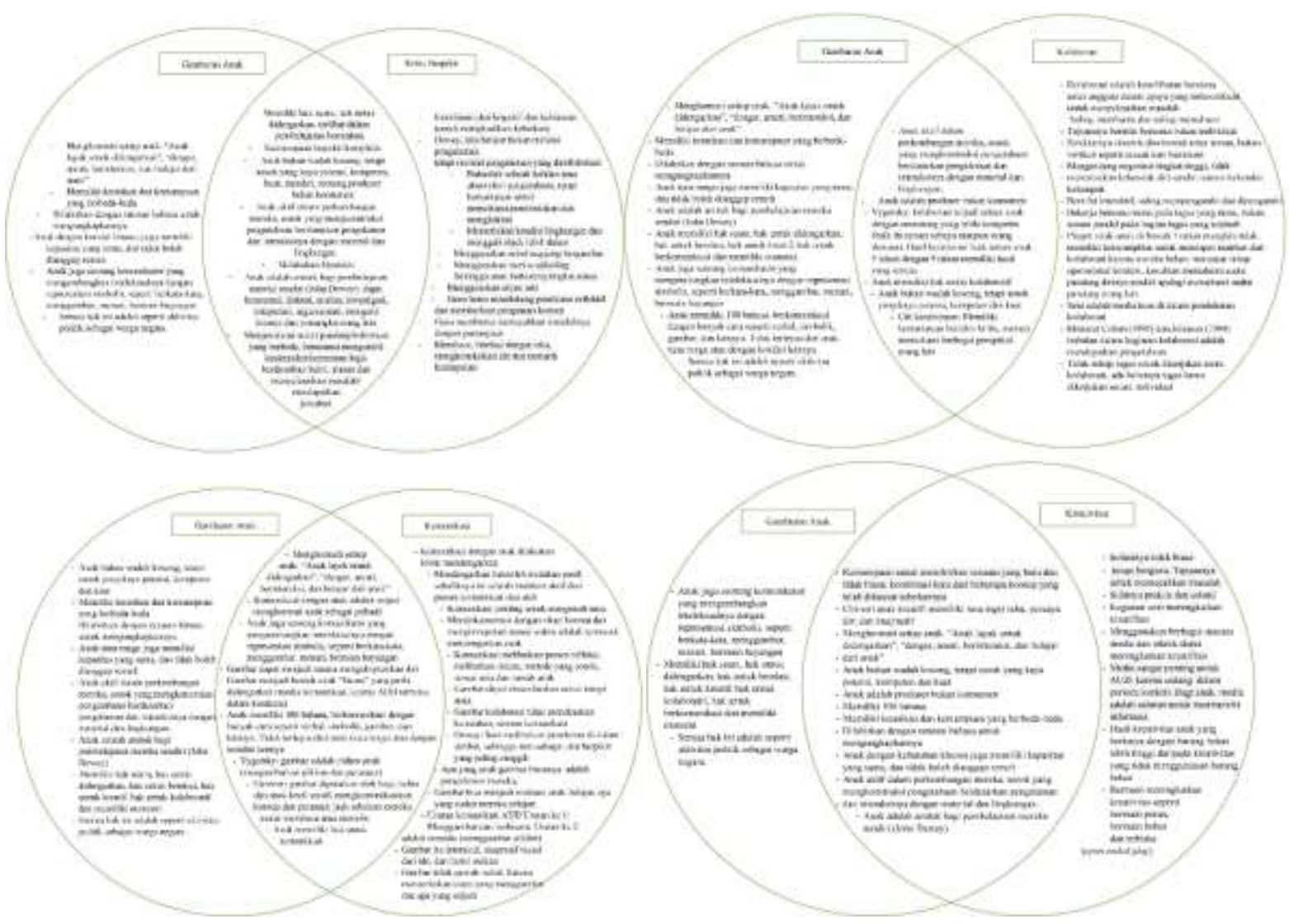

Gambar 3. Diagram Vann: “Gambaran anak menurut Pendekatan Reggio Emilia dengan Kemampuan abad ke-21"

\section{Gambaran anak dari Pendekatan Reggio Emilia dapat menjawab tantangan kemampuan abad ke-21}

Pendekatan Reggio Emilia melihat anak harus dihormati, anak bukan wadah kosong melainkan memiliki potensi, memiliki 100 bahasa, seorang arsitek bagi pembelajarannya, berhak untuk kreatif, berhak untuk berelasi dan didengarkan. Anak dapat melakukan berpikir kompleks, membuat hipotesis, melakukan evaluasi dari sudut pandang yang berbeda dan mengambil kesimpulan darinya. Dengan prinsip seperti ini, maka anak akan diberikan kebebasan sehingga menunjang kemampuan kritis berpikirnya.

Berdasarkan diagram yang ada pada gambar 3, dapat dilihat bahwa gambaran tentang anak yang positif, berpotensi, memiliki 100 bahasa adalah kunci menuju kreativitas. Terlebih lagi Pendekatan Reggio Emilia melihat anak memiliki banyak hak, salah satunya adalah berhak untuk kreatif. Anak dilihat sebagai sosok yang membangun pengetahuannya lewat interaksi dengan lingkungannya. Konsep ini menggambarkan bahwa filosofi Pendekatan Reggio Emilia sesuai dengan konsep kolaborasi.

Menurut teori komunikasi, cara menghormati anak sebagai pribadi adalah dengan cara mendengarkannya. Hal inilah yang sangat menonjol dari Pendekatan Reggio Emilia yaitu anak layak untuk didengarkan karena mereka terlahir dengan 100 bahasa yang perlu untuk diungkapkan dan didengarkan. Pendekatan Reggio Emilia melihat anak juga seorang komunikator yang dapat berkomunikasi lewat banyak media (gambar, tulisan, bermain, menari, berkata-kara, menggunakan simbol, dll). Anak-anak sangat dihargai karena setiap anak dilihat sebagai "warga negara" yang utuh. 

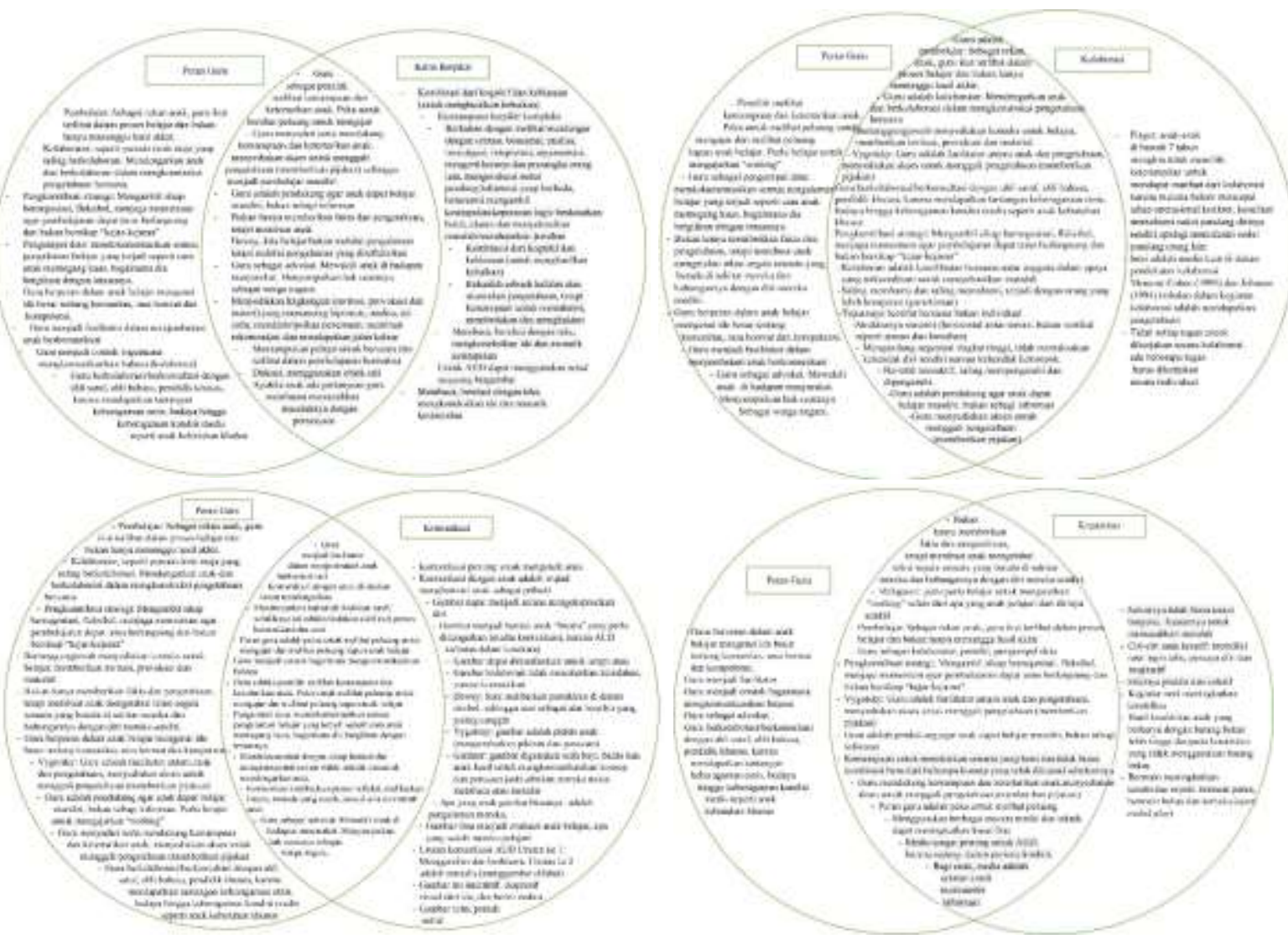

Gambar 4. Diagram Vann: “Peran Guru menurut Pendekatan Reggio Emilia dengan Kemampuan abad ke-21"

\section{Peran Guru menurut Pendekatan Reggio Emilia dapat menjawab tantangan kemampuan abad ke-21}

Guru menurut Pendekatan Reggio Emilia yang ada di dalam gambar 4 dapat membantu anak menjadi wakil di masyarakat, peka terhadap peluang, menyediakan lingkungan berupa invitasi, provokasi dan material, menyediakan pijakan agar anak menjadi pembelajar yang mandiri, terbuka untuk berdiskusi dan menjalin relasi dengan situasi di sekitar mereka (dapat merefleksikan lingkungan dengan diri mereka). Menjalin relasi, memahami lingkungan dan pengalian objek dengan lebih mendalam adalah salah satu cara menuju kritis berpikir.

Guru menjadi seorang peneliti, tidak menyuapi anak dengan pengetahuan, guru mendengarkan anak, dan mendukung ketertarikan anak. Disaat anak ada masalah guru di Pendekatan Reggio Emilia tidak langsung memberikan jawabnnya melainkan memberikan pertanyaan lain yang menggiring anak untuk lebih kritis dan menemukan jawabannya sendiri. Hal ini mendukung konsep kritis berpikir yaitu belajar lewat pengalaman yang direfleksikan dan menjadikan pembelajaran bermakna.

Loris Malaguzzi mengatakan bahwa guru di RE perlu untuk mengajarkan "nothing" selain dari apa yang anak itu pelajari dari dirinya sendiri. Bersikap sebagai fasilitator, peneliti dan pemberi pijakan sehingga anak dapat menjadi pembelajar mandiri. Guru juga memberikan kesempatan bagi anak untuk bermain bebas, ini semua penting bagi anak karena dengan kesempatan yang luas seperti ini anak dapat memikirkan hal yang baru dan tidak monoton, dimana ini adalah ciri-ciri kreatif.

Guru dilihat sebagai rekan, kolaborator yang bertugas mendengarkan anak, menata lingkungan (provokasi, invitasi) dan memberikan pijakan yang bertujuan menyusun pengetahuan bersama. Guru seringkali berkolaborasi dengan para ahli seperti ahli saraf, ahli bahasa, psikolog, tenaga medis, dll untuk mengerti kondisi anak, sehingga anak dapat 
difasilitasi dengan baik. Guru mengambil sikap negosisasi dan fleksibel saat melakukan proyek, mengikuti kecepatan anak dalam memahami suatu pembelajaran dan tidak terburuburu memberikan batas waktu, juga bukan seperti atasan yang memerintah atau sebagai seorang informan yang mendiktekan pegetahuan. Tetapi sebagai sosok yang saling berdampingan dengan anak dalam menyusun pengetahuan.

Guru dalam pendekatan ini sangat berperan penting dalam berkomunikasi dengan anak. Karena guru berada diantara masyarakat dan anak. Guru sebagai advokat yang harus menyuarakan suara anak di masyarakat. Begitu pula guru di sekolah mewakili masyarakat untuk mendidik anak. Kedua peran ini ditopang oleh komunikasi. Guru menjadi contoh bagaimana cara berkomunikasi.
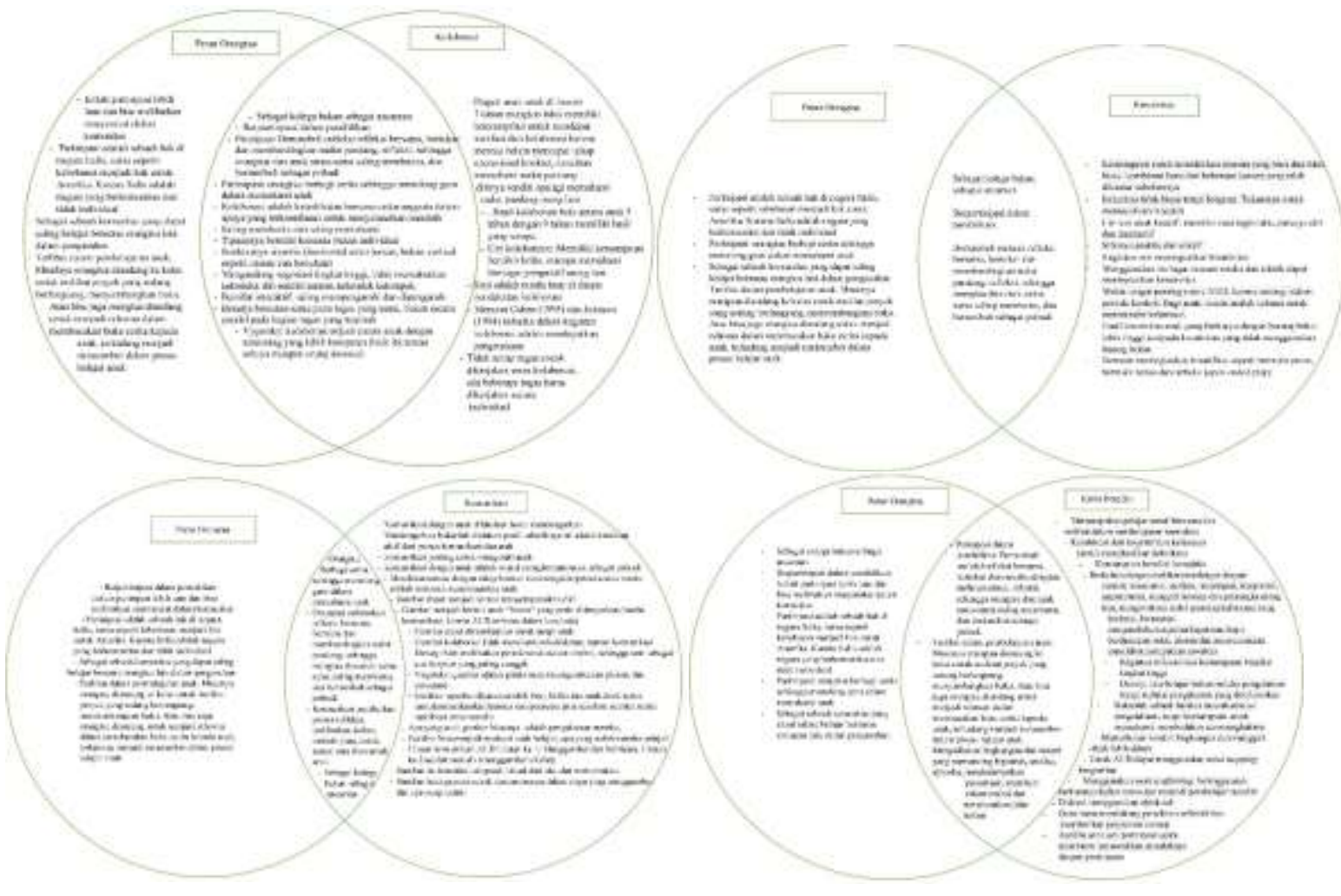

Gambar 5. Diagram Vann: “Peran Orangtua menurut Pendekatan Reggio Emilia dengan Kemampuan abad ke-21"

\section{Peran Orangtua menurut Pendekatan Reggio Emilia dapat menjawab tantangan kemampuan abad ke-21}

Pada gambar 5, dapat dilihat bahwa peran orangtua tidak kalah penting dalam mengembangkan kemampuan abad ke-21, karena orangtua menjadi rekan dalam bertumbuh bersama anak. Juga sebagai rekan guru yang turut berperan dalam menyediakan lingkungan dan material, menjadi relawan dan narasumber dalam proses investigasi, diskusi, dan penyusunan hipotesis. Peran orangtua menjadi jendela bagi anak untuk mencapai kritis berpikir. Karena apabila orangtua tidak mendukung pendidikan di sekolah, maka kritis berpikir pada anak akan sulit dicapai.

Orangtua dalam Pendekatan Reggio Emilia berperan sebagai kolega bagi guru dan anak dalam pembelajaran. Orangtua diposisikan sebagai sosok untuk bertukar pikiran dan membandingkan sudut pandang, saling bertumbuh bersama anak dan mendukung anak dalam menyediakan materi. Hal ini penting bagi perkembangan kreativitas anak. Karena salah satu cara untuk mengembangkan kreativitas adalah dengan penyediaan materi dan kesempatan eksplorasi. 
Keterlibatan dari orangtua ini sifatnya demi pembelajaran anak yang sifatnya komunal bukan individual. Orangtua di pendekatan ini tidak menuntut sekolah dan guru melayani harapan dan ekspektasi dirinya. Namun bersama dengan sekolah saling bekolaborasi demi pendidikan anak. Komunikasi juga terjalin baik dengan guru, dengan anak dan dengan orangtua lain. Orangtua berperan sebagai kolega dalam pembelajaran dan juga sebagai komunitas yang bertumbuh bersama orangtua lain di dalam pengasuhan anak.

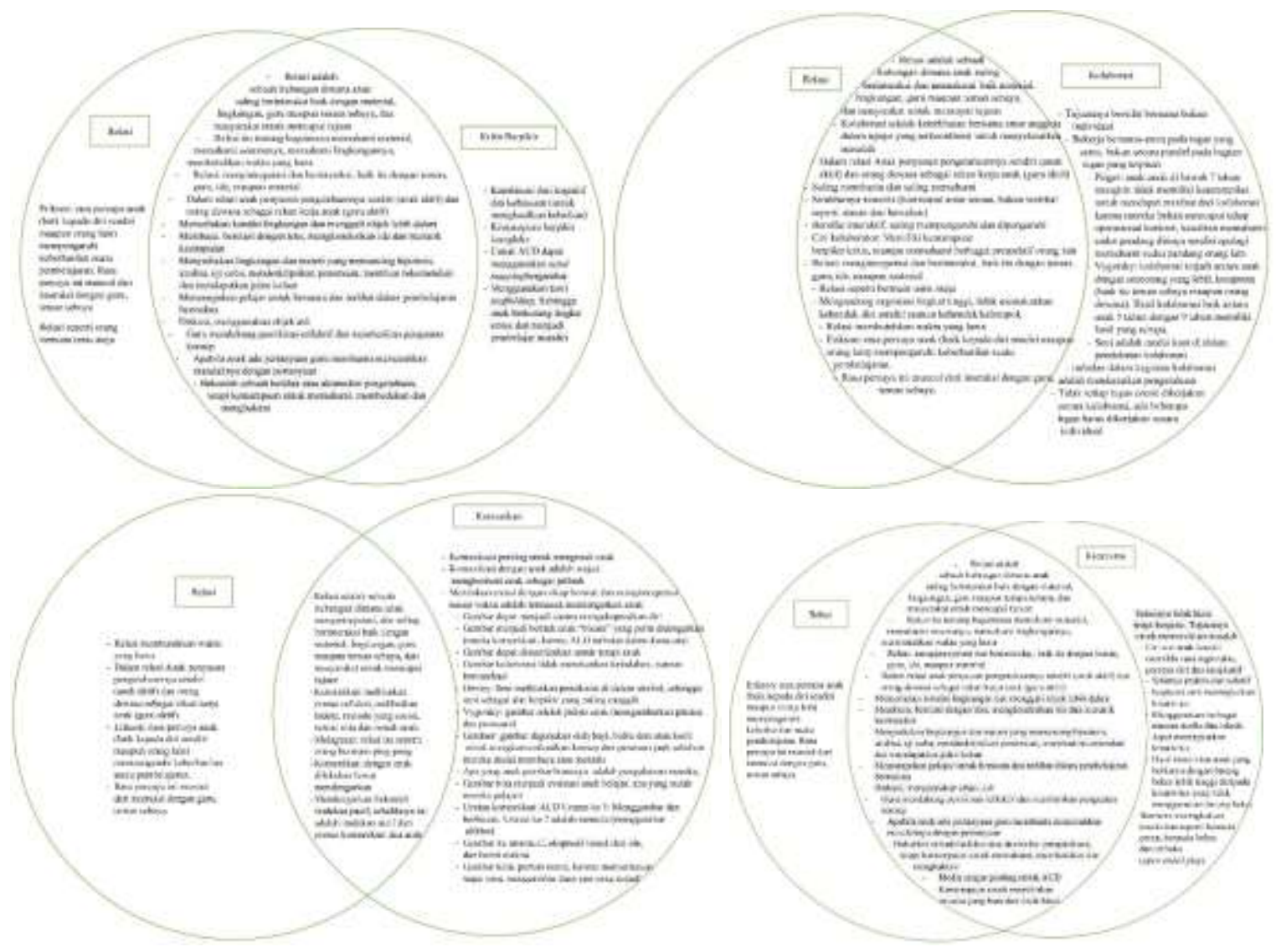

Gambar 6. Diagram Vann: “Relasi menurut Pendekatan Reggio Emilia dengan Kemampuan abad ke-21"

\section{Relasi menurut Pendekatan Reggio Emilia dapat menjawab tantangan kemampuan abad} ke-21

Dapat dilihat pada gambar 6, bahwa relasi adalah sesuatu hal yang menjanjikan dalam mengembangkan kemampuan kritis berpikir, karena ini adalah suatu keadaan yang memahami material, memahami teman, lingkungan dan kondisi yang terjadi. Pemahamaan ini akan membuka jalan bagi anak ke dalam kritis berpikir yang memiliki komponen mampu memahami, membangun pikiran reflektif, membedakan, membangun hipotesis, menghakimi, dan menyelesaikan masalah.

Relasi adalah suatu hubungan dimana anak berinteraksi dengan material, teman sebaya, guru dan lingkungan untuk mencapai suatu tujuan. Relasi membutuhkan waktu dalam memahami material, orang lain maupun kondisi yang terjadi. Sedangkan kreativitas dapat muncul jika seseorang memiliki pemahaman terhadap suatu barang, situasi, dan solusi yang selama ini sudah pernah diambil. Dengan memahami ini maka seseorang dapat memikirkan sesuatu yang berbeda dari sebelumnya. Inilah peran relasi dalam mengembangkan kemampuan kreativitas.

Relasi menjadi penting dalam proses belajar di Pendekatan Reggio Emilia, tanpa relasi baik dengan material, guru maupun teman sebaya pembelajaran tidak akan pernah terjadi. Dalam berelasi ini anak perlu memahami material maupun individu yang bekerja sama 
dengan dia, dan inilah ciri dari kolaborator. Konsep relasi memiliki konsep yang sama dengan kolaborasi, yaitu saling berinteraksi, saling mempengaruhi dan dipengaruhi. Seperti permainan tenis meja yang akan berhenti bila salah satu pemain berhenti berespon. Melihat diagram diatas bahwa konsep relasi sepenuhnya cocok dengan kolaborasi, dapat dikatakan relasi dalam Pendekatan Reggio Emilia adalah teori kolaborasi itu sendiri.

Komunikasi dan relasi memiliki beberapa prinsip dasar yang sama, seperti ada proses intrepetasi, refleksi, melibatkan indera, menggunakan metode yang cocok. Relasi digambarkan sebagai permainan tenis meja, harus melibatkan dua pihak, begitu juga dengan komunikasi.
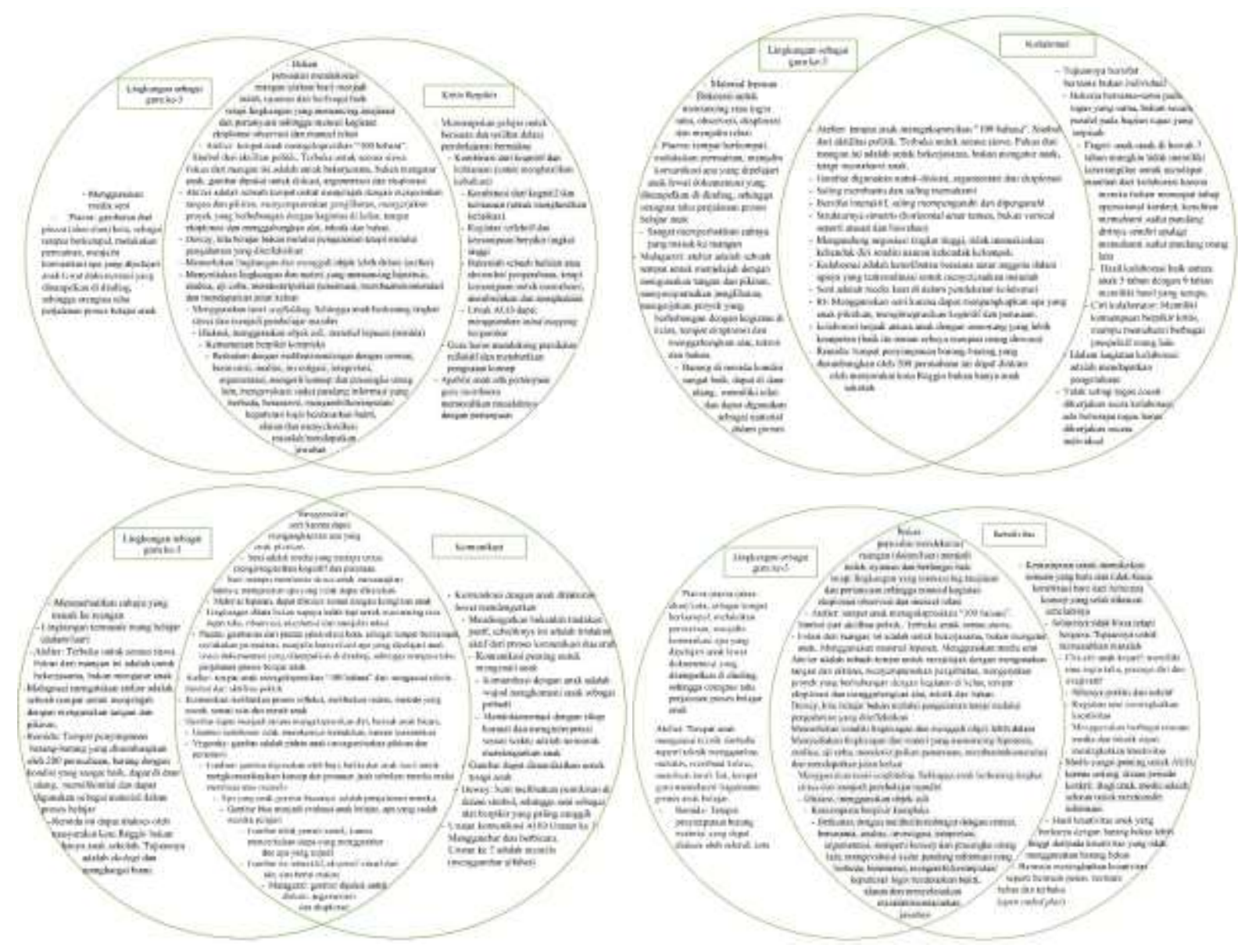

Gambar 7. Diagram Vann: “Lingkungan sebagai guru ke-3 dengan Kemampuan abad ke-21”

\section{Lingkungan di Pendekatan Reggio Emilia dapat menjawab tantangan kemampuan abad ke-} 21

Pada gambar 7, dapat dilihat bahwa lingkungan sangat mempengaruhi perkembangan kemampuan abad ke-21. Lingkungan di Pendekatan Reggio Emilia ditata dengan baik, dari arah cahaya yang masuk, peyediaan alat dan bahan yang beragam (termasuk media teknologi) juga penyediaan material terbuka. Hal ini dilakukan untuk memancing relasi, observasi, dan eksplorasi. Mendukung anak dalam investigasi, membuat anak berpikir kritis. Penyediaan material ini selalu menggunakan objek asli, baik itu yang di alam maupun buatan pabrik. Penyediaan material asli ini memancing kritis berpikir pada anak.

Lingkungan juga termasuk dengan atelier, sebuah studio tempat dimana anak bebas mengeksplorasi berbagai macam alat, bahan dan melakukan berbagai kegiatan seni seperti menggunakan cat, tanah liat, cahaya, proyektor, alat musik, dll. Lingkungan ini adalah lingkungan yang subur dalam mengembangkan kreativitas anak. Anak bebas mengeksplorasi dan menggunakan berbagai macam alat dan bahan untuk membuat karya seni. Teori 
kolaborasi mengatakan bahwa seni adalah media kuat dalam berkolaborasi, maka sebetulnya Atelier mendukung kemampuan kolaborasi pada anak.

Selain atelier, remida juga adalah salah satu tempat istimewa bagi Pendekatan Reggio Emilia. Remida, sebuah tempat penyimpanan material terbuka yang merupakan sumbangan dari 200 perusahaan di kota Reggio Emilia. Barang di Remida bebas diakses oleh siapa saja baik sekolah maupun warga masyarakat di sekitar kota Reggio Emilia. Tempat ini sebagai bukti bahwa di dalam pendekatan ini masyarakat turut berkolaborasi dengan sekolah dalam hal pendidikan. Pendekatan Reggio Emilia yang menggunakan seni dalam pembelajarannya selaras dengan teori berkomunikasi dengan anak, yaitu melalui kegiatan seni. Menurut Vygotsky gambar adalah bentuk pidato anak.
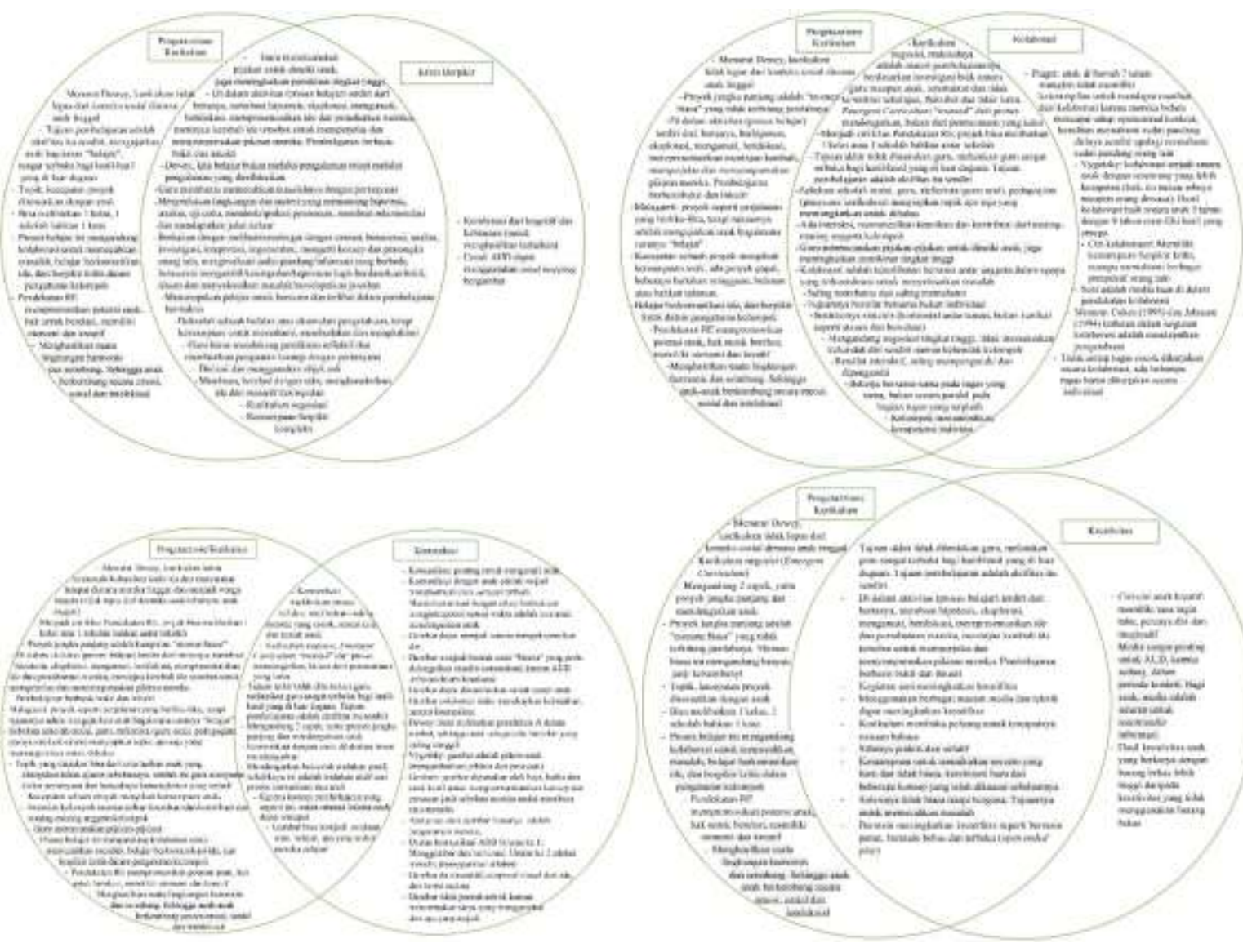

Gambar 8. Diagram Vann: “Kurikulum Pendekatan Reggio Emilia dengan Kemampuan abad ke$21^{\prime \prime}$

Kurikulum Pendekatan Reggio Emilia dapat menjawab tantangan kemampuan abad ke-21

Gambar 8 memperlihatkan bahwa kurikulum di Pendekatan Reggio Emilia dapat mengembangkan kemampuan abad ke-21. Kurikulum pada pendekatan ini menggunakan proyek jangka panjang dan kurikulum negosiasi (emergent) yang muncul dari mendengarkan anak, bukan melalui perencanaan yang kaku dan ini merupakan dasar dari komunikasi. Pendekatan ini memakai proyek jangka panjang, yang adalah kumpulan "momen biasa" yang tidak terhitung jumlahnya. Pendekatan Reggio Emilia melihat setiap momen biasa ini mengandung banyak janji tersembunyi, yang menggiring hasil pembelajaran yang tidak terduga dan terbuka. Proses pembelajaran tidak terburu-buru dan menggunakan teori scaffolding, dan secara keseluruhan kurikulum seperti ini tentunya mendukung terjadinya kritis berpikir. 
Kurikulum pada pendekatan ini bersifat terbuka dan negosiatif, mendengarkan minat anak, dan mengizinkan anak untuk menjadi penentu pembelajaran. Tidak ada suatu tujuan kaku dengan indikator yang harus dicapai. Tujuan dari pembelajaran ini adalah "aktifitas" itu sendiri dan melahirkan 100 bahasa anak. Maka anak dibebaskan untuk eksplorasi dan melakukan aktivitas kreativitas dengan bahan dan teknik apapun. Sifatnya terbuka dengan tujuan anak memperoleh jawaban dari permasalahannya. Ini semua sangat mendukung kemampuan kreatif anak.

Peserta dalam pembelajaran proyek di pendekatan ini dapat berisi satu kelas, bahkan satu sekolah dari usia batita sampai usia 8 tahun. Dalam penyusunan kurikulum guru mempersiapkannya bersama dengan atelierista (guru studio) dan saling berbagi sudut pandang mengenai topik yang akan dijadikan proyek. Hal ini adalah tindakan kolaborasi.
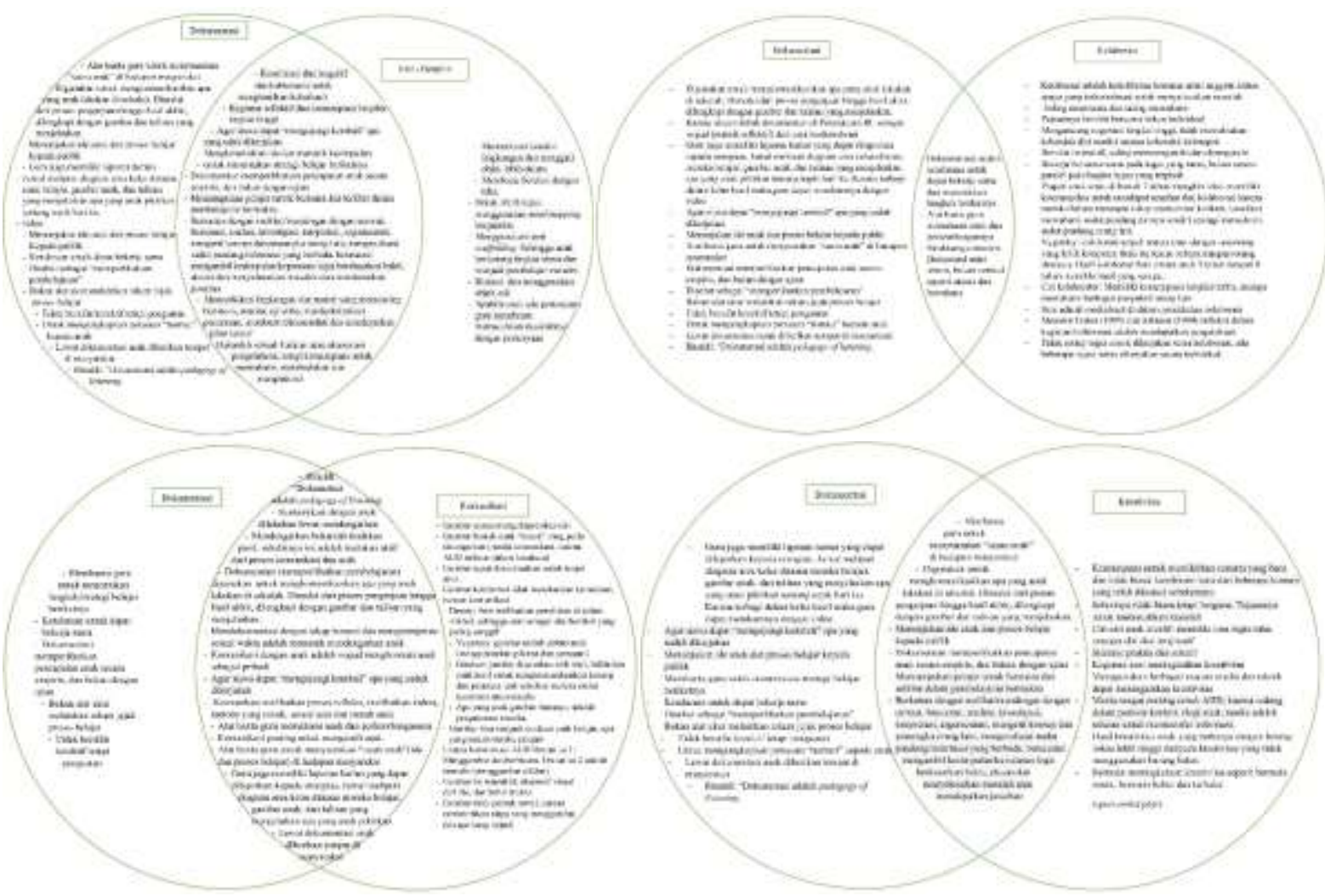

Gambar 9. Diagram Vann: “Dokumentasi Pendekatan Reggio Emilia dengan Kemampuan abad ke$21^{\prime \prime}$

\section{Dokumentasi Pendekatan Reggio Emilia dapat menjawab tantangan kemampuan abad ke-} 21

Asesmen dari pendekatan ini adalah menggunakan dokumentasi yang sifatnya terbuka dan bukan untuk memenuhi indikator yang sudah ditetapkan sebelumnya. Dokumentasi juga bersifat dapat dikunjungi berulang kali, hal ini membuat anak tidak terbeban dalam menjalani proses pembelajaran. Anak dilatih untuk mengetahui kesalahnnya sendiri, mencari kebenaran dan mengkoreksi diri sendiri. Dokumentasi membuat anak menjadi belajar bagaimana caranya belajar, bukan hanya mempelajari konten saja. Dokumentasi juga mendukung anak untuk lebih berani bereksplorasi dan mengeluarkan pendapatnya, terpacu untuk berinovasi, mengkoneksikan ide dan berpikir kritis karena bersifat empiris dan tidak terikat dengan pencapaian seperti ujian.

Dokumentasi memperlihatkan kemampuan anak pada awal mula pembelajaran sampai kepada akhir pembelajaran dengan pemikiran yang lebih kompleks. Karena asesmennya seperti ini maka anak lebih terbuka dan berani untuk bereksplorasi dan kreatif. 
Asesmen yang berupa dokumentasi dapat menjadi media kolaborasi antara guru dan anak. Keduanya akan saling mengunjungi ulang hasil pembelajaran, melakukan refleksi dan kemudian menentukan langkah berikutnya. Dapat dikatakan dokumentasi sebagai jendela menuju kolaborasi yang menghasilkan kurikulum pembelajaran.

Dokumentasi tidak akan terjadi dengan baik bila tidak ada unsur komunikasi di dalamnya. Dokumentasi biasanya menyertakan perkataan anak tentang suatu teori yang sedang dipelajarinya. Lewat dokumentasi, apa yang dipikirkan anak dapat dikomunikasikan ke masyarakat, sehingga dokumentasi disebut sebagai "memperlihatkan pembelajaran" atau juga disebut sebagai "pedagogi mendengarkan".

\section{Melihat Pendekatan Reggio Emilia dalam konteks Pendidikan Indonesia menurut Ki Hajar Dewantara}

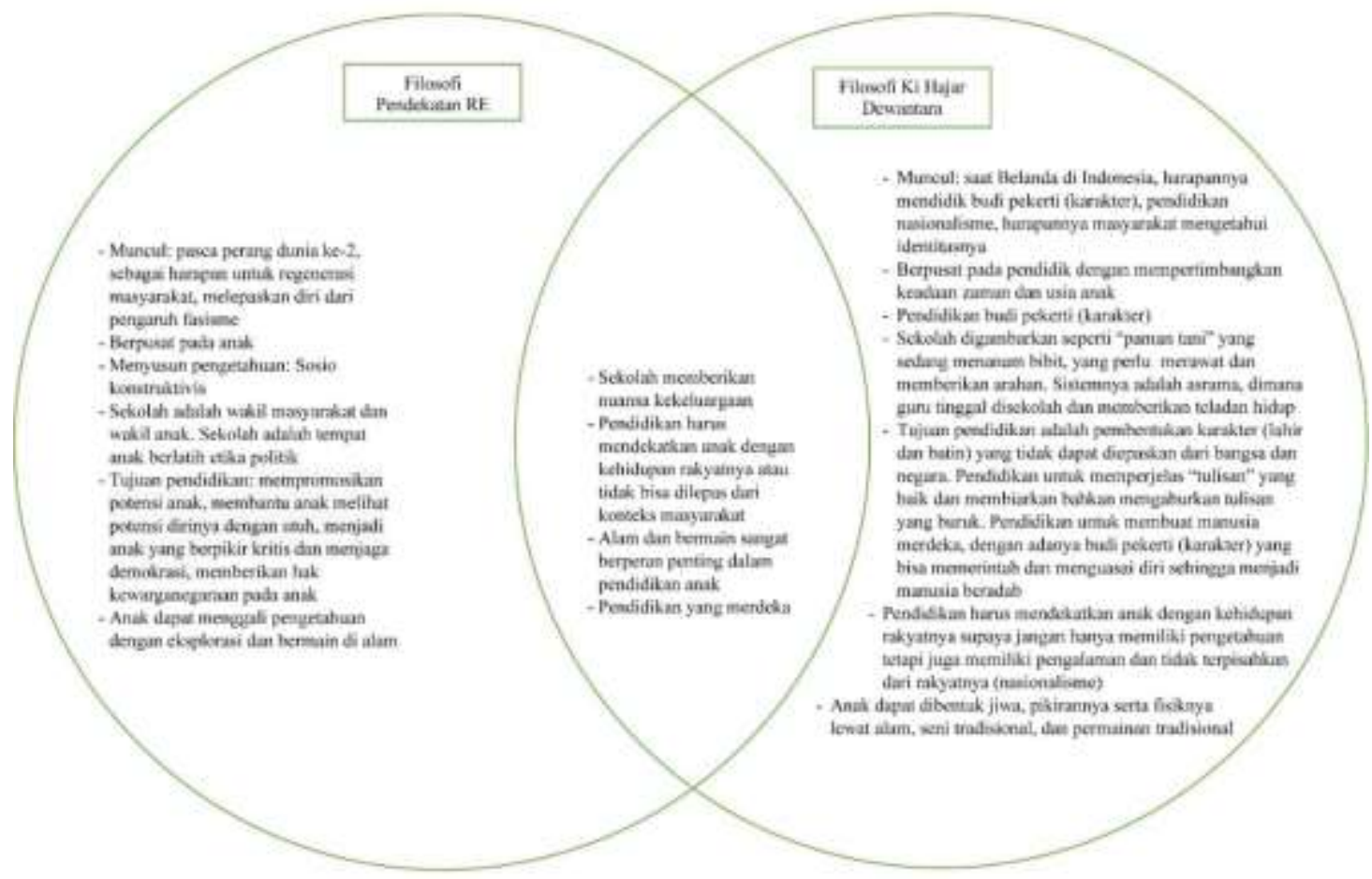

Gambar 10. Diagram Vann: “Filosofi Pendekatan Reggio Emilia dengan Filosofi Pendidikan Ki Hajar Dewantara"

Pada gambar 10 di atas, dapat dilihat bahwa filosofi dari Pendekatan Reggio Emilia dan filosofi pendidikan menurut Ki Hajar Dewantara memiliki beberapa kesamaan, yaitu sama-sama berpendapat bahwa pendidikan tidak dapat dilepaskan dari konteks masyarakat. Anak harus dididik mengenal lingkungannya dimana alam dan kegiatan bermain sangat berperan penting dalam proses pendidikan. Lingkungan sekolah juga harus memberikan suasana kekeluargaan bukan suasana individualistis.

Keduanya baik Pendekatan Reggio Emilia maupun pendidikan menurut Ki Hajar Dewantara muncul sebagai respon terhadap keadaan politik saat itu, dimana pendekatan Reggio Emilia adalah respon dari Fascism dan Pendidikan Ki Hajar Dewantara merupakan respon dari penjajahan Belanda. Keduanya ingin bebas, ingin menghasilkan anak-anak yang merdeka. Tetapi meskipun memiliki beberapa kesamaan, namun kedua pendidikan ini memiliki perbedaan yang tidak sedikit, salah satunya terletak pada orientasi pendidikan. Pendekatan Reggio Emilia berorientasi pada anak, sedangkan pendidikan Ki Hajar Dewantara lebih cenderung berorientasi pada guru, meskipun Ki Hajar Dewantara yang terinspirasi oleh Montessori dan Froebel juga banyak membicarakan soal hak dan kebebasan anak. 
DOI: 10.31004/obsesi.v6i1.1228

Konsep mengenai pribadi yang merdeka juga ada perbedaan. Merdeka menurut Pendekatan Reggio Emilia adalah anak yang berhak bicara, berhak didengarkan, berhak secara individual dan mempunyai hak suara sebagai warga negara yang utuh dan sekolah adalah sebuah tempat untuk berlatih etika politik. Sedangkan konsep anak yang merdeka menurut Ki Hajar Dewantara adalah anak yang mengenal identitas dirinya dan bangsanya (pendidikan nasional) serta berbudi pekerti (pendidikan karakter). Konsep sekolah menurut Ki Hajar Dewantara adalah asrama, dimana guru tinggal di dalam sekolah dan memberikan teladan hidup kepada murid-muridnya.

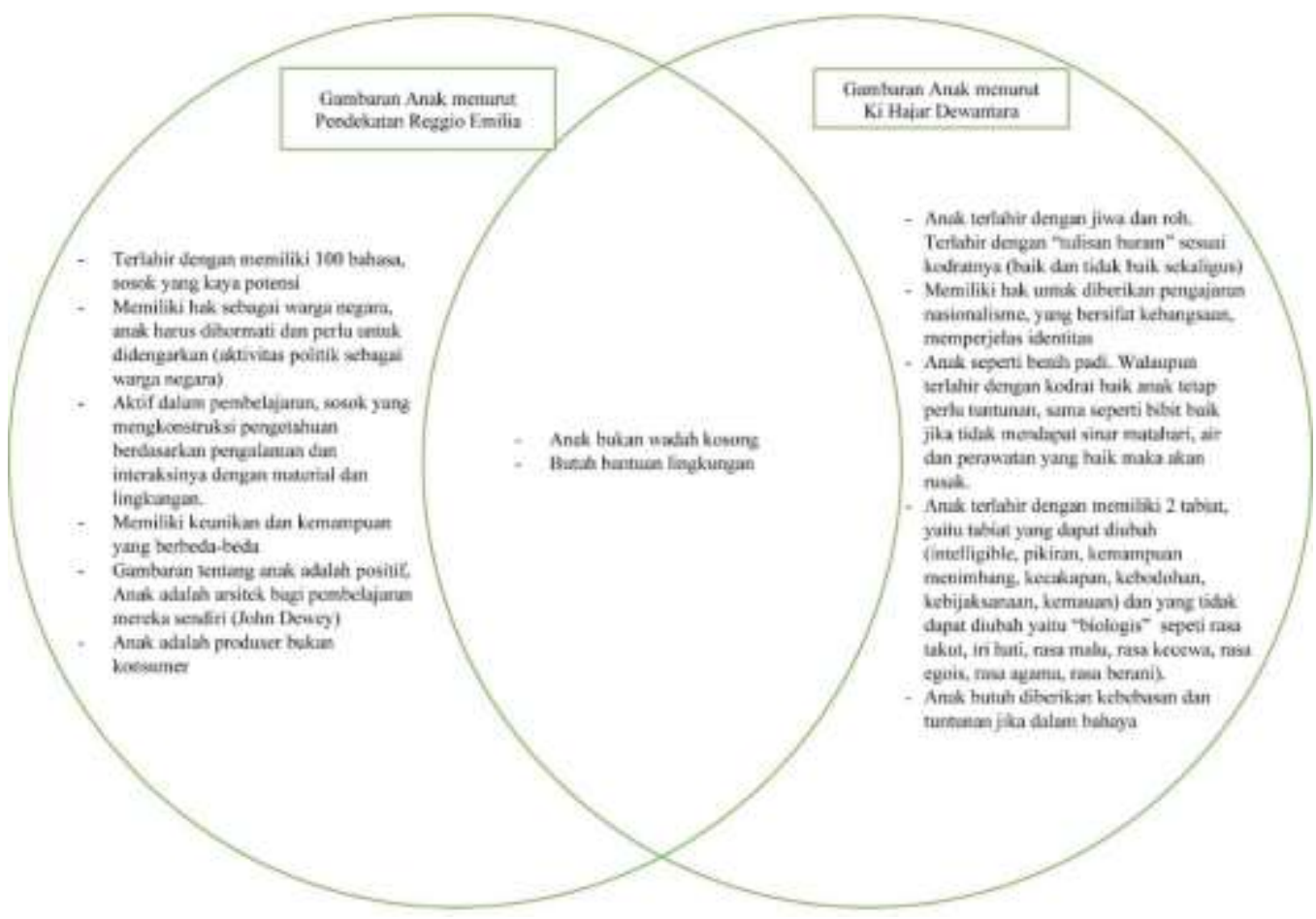

\section{Gambar 11. Diagram Vann: “Gambaran anak menurut Pendekatan Reggio Emilia dengan Gambaran anak menurut Pendidikan Ki Hajar Dewantara"}

Gambar 11 memperlihatkan bahwa gambaran anak menurut Pendekatan Reggio Emilia memiliki kesamaan dengan pandangan anak menurut Ki Hajar Dewantara bahwa anak terlahir bukan seperti wadah kosong, dan memerlukan bantuan lingkungan dalam bertumbuh. Tetapi konsep bukan wadah kosong ini sangat menarik untuk diselidiki lebih lanjut. Karena Pendekatan Reggio Emilia melihat anak terlahir dengan potensi positif. Maka dari itu anak membutuhkan lingkungan agar dapat membantu anak mengeluarkan seluruh potensi positif yang berada di dalam dirinya.

Sedangkan Ki Hajar Dewantara memiliki pandangan bahwa anak terlahir dengan potensi positif dan negatif sekaligus. Maka dari itu anak membutuhkan lingkungan untuk membantunya untuk mempertegas potensi postif dan mengaburkan potensi negatif. Gambaran anak ini adalah kunci utama dalam pendidikan, karena gambaran anak adalah sebuah presuposisi atau asumsi dasar yang mempengaruhi seluruh sudut pandang. Tentu asumsi dasar ini juga menentukan komponen apa saja yang ada di dalam sebuah pendekatan, seperti metode yang digunakan, model relasi seperti apakah yang akan dibangun, materi dan material apa saja yang akan diberikan hingga ke cara mengevaluasi pembelajaran. 


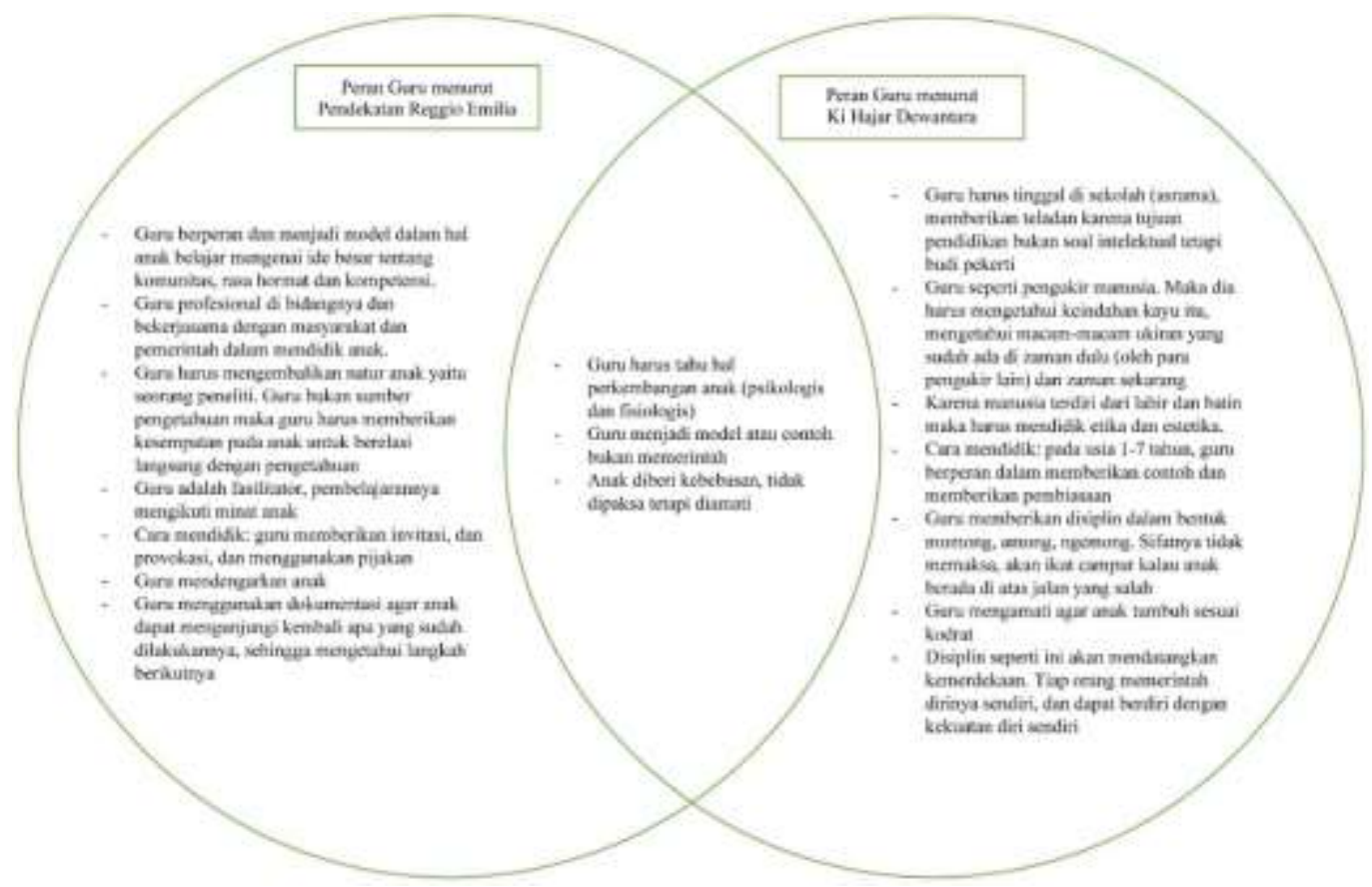

Gambar 12. Diagram Vann: “Peran guru menurut Pendekatan Reggio Emilia dengan peran puru menurut Pendidikan Ki Hajar Dewantara"

Gambar 12 menunjukan, pandangan guru menurut Pendekatan Reggio Emilia dan menurut Ki Hajar Dewantara memiliki beberapa persamaan yaitu guru harus mengetahui perkembangan anak, baik secara psikologis maupun fisiologis. Guru harus memberikan kebebasan pada anak, bukan memaksa anak tetapi mengamatinya, dan guru menjadi model bagi anak bukan pemerintah anak. Namun sekali lagi terdapat perbedaan diantaranya. Hal ini disebabkan oleh gambaran anak yang berbeda, sehingga mempengaruhi peran guru yang berbeda pula.

Dalam pendekatan Reggio Emilia, guru dilihat sebagai fasilitator dan mediator antara anak dan ilmu pengetahuan. Tetapi Ki Hajar Dewantara melihat guru adalah pemberi teladan dan berperan dalam pengasuhan. Sedang Pendekatan Reggio Emilia tidak pernah membicarakan mengenai pengasuhan anak. Meskipun guru di Pendekatan Reggio Emilia dikatakan menjadi contoh dalam berkomunitas dan menunjukan rasa hormat, tetapi hal ini dalam konteks penggalian informasi dan berkomunitas bukan dalam konteks pembentukan karakter dan budi pekerti.

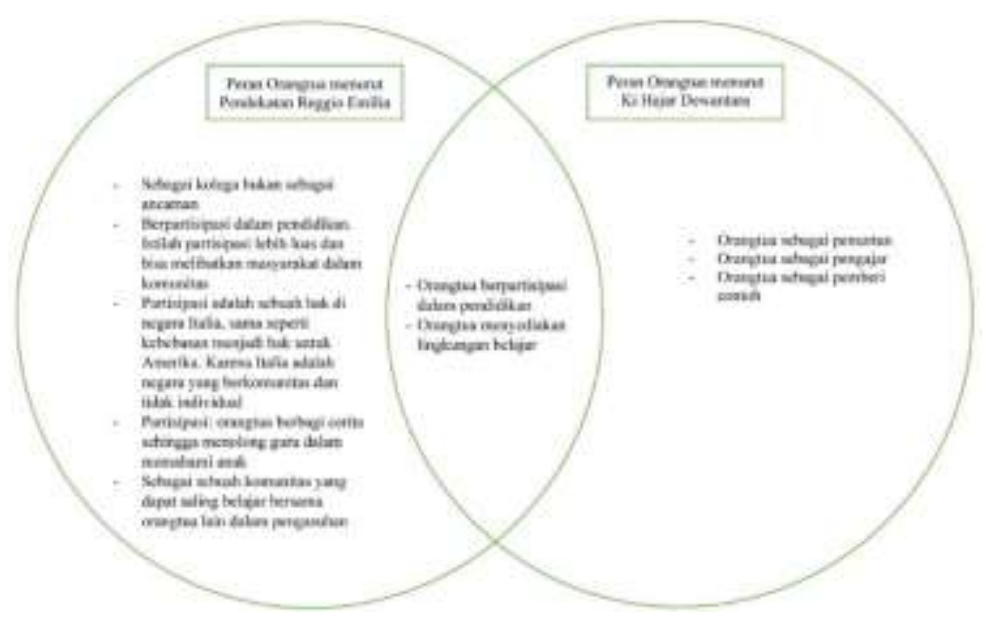

Gambar 13. Diagram Vann: “Peran orangtua menurut Pendekatan Reggio Emilia dengan peran orangtua menurut Pendidikan Ki Hajar Dewantara" 
DOI: 10.31004/obsesi.v6i1.1228

Hubungan orangtua di Reggio Emilia yang dibicarakan adalah dalam konteks peroses belajar yang bekerjasama dengan sekolah. Sedangkan dalam pandangan Ki Hajar Dewantara peran orangtua adalah dalam pengasuhan dan pemberian teladan dalam kehidupan. Namun begitu Pendekatan Reggio Emilia dan Ki Hajar Dewantara memiliki beberapa kesamaan seperti yang dapat dilihat pad gambar 13.

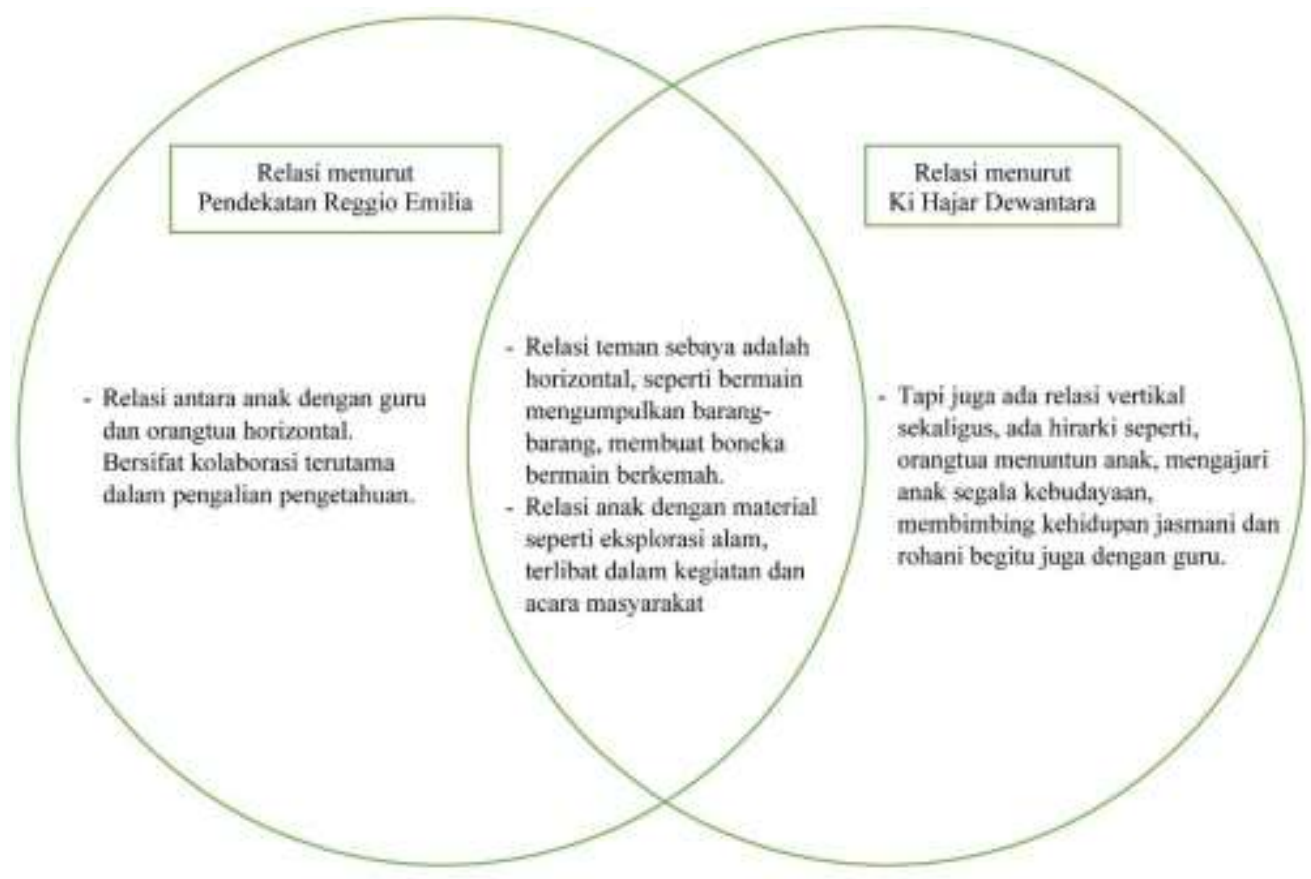

Gambar 14. Diagram Vann: “Konsep relasi menurut Pendekatan Reggio Emilia dengan Konsep relasi menurut Pendidikan Ki Hajar Dewantara"

Pendekatan Reggio Emilia pada gambar 14, tidak membicarakan soal pengasuhan seperti yang dibicarakan oleh Ki Hajar Dewantara. Pendekatan Reggio Emilia berbicara dalam konteks penggalian ilmu pengetahuan. Maka relasi anak menurut Pendekatan Reggio Emilia adalah horizontal, baik dengan teman sebaya, guru, orangtua maupun material. Sedangkan menurut Ki Hajar Dewantara relasi anak dengan guru dan orangtua adalah relasi vertikal karena ada pemodelan, dan bimbingan secara rohani. Sedangkan relasi anak dengan teman sebaya dan material adalah horizontal.

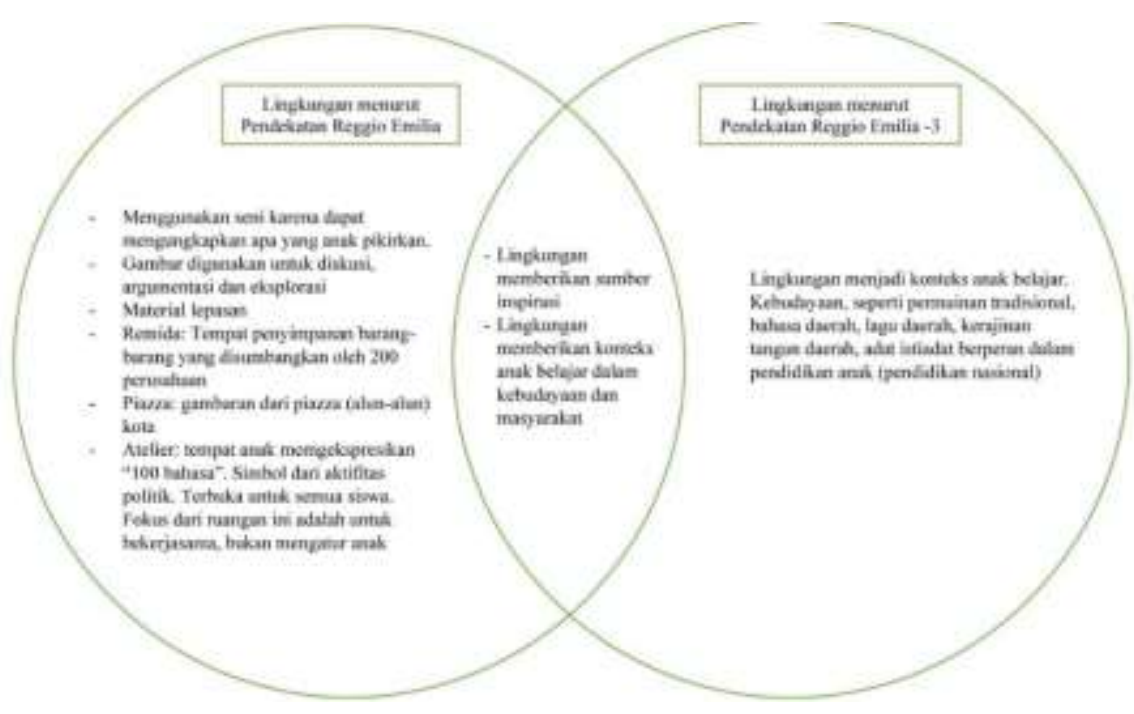

Gambar 15. Diagram Vann: “Konsep lingkungan menurut Pendekatan Reggio Emilia dengan Konsep lingkungan menurut Pendidikan Ki Hajar Dewantara" 
Gambar 15 menunjukan bahwa konsep lingkungan dari Pendekatan Reggio Emilia memiliki kesamaan dengan pandangan Ki Hajar Dewantara. Namun, keduanya juga memiliki perbedaan seperti Pendekatan Reggio Emilia memakai seni sebagai media anak berkomunikasi dan mengekspresikan 100 bahasa. Sedangkan, Ki Hajar Dewantara memakai seni untuk pendidikan nasional yaitu mengajarkan identitas bangsa. Seni juga digunakan untuk keseimbangan, membangun etika dan estetika sekaligus (tata krama). Dalam hal ini Ki Hajar Dewantara terinspirasi oleh Rudolf Steiner.

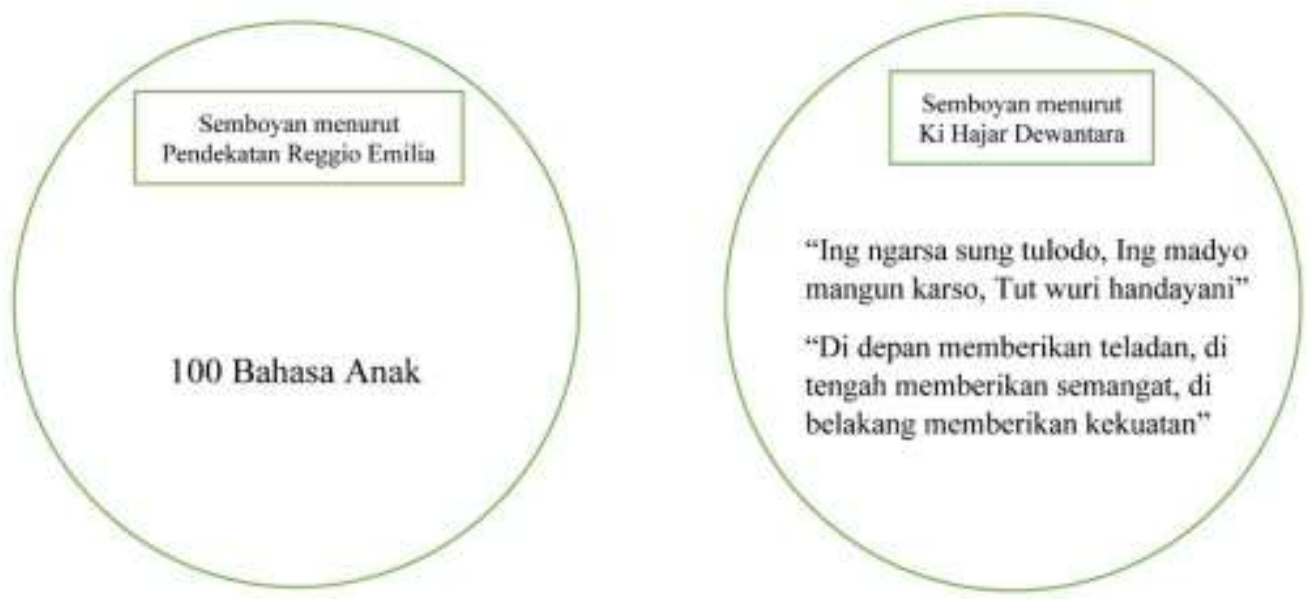

Gambar 16. Diagram Vann: “Semboyan Pendekatan Reggio Emilia dengan semboyan Ki Hajar Dewantara"

Pada gambar 16, dapat dilihat tidak ada konsep yang bersinggungan. Semboyan Pendekatan Reggio Emilia adalah 100 bahasa anak, semboyan Ki Hajar Dewantara adalah "Ing ngarsa sung tulodo, Ing madyo mangun karso, Tut wuri handayani". Dari semboyan ini kita dapat melihat bahwa Pendekatan Reggio Emilia berpusat pada anak, sedangkan pendidikan menurut Ki Hajar Dewantara berpusat pada guru.

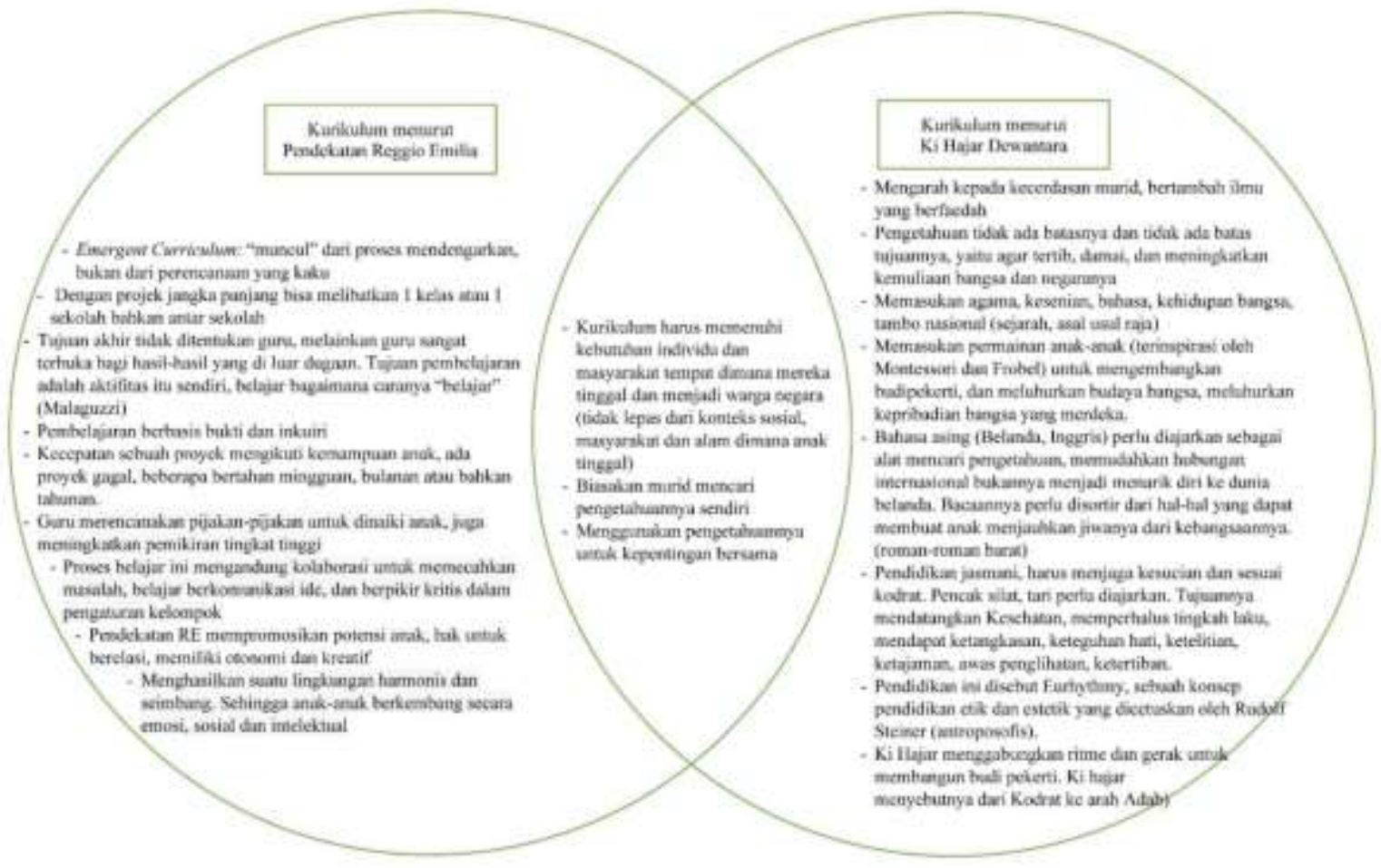

Gambar 17. Diagram Vann: “Kurikulum Pendekatan Reggio Emilia dengan kurikulum Ki Hajar Dewantara" 
Jikalau Loris Malaguzzi dalam mengkonsepkan Pendekatan Reggio Emilia memiliki banyak terpengaruh dari John Dewey, Piaget, Vygotsky dan Bruner dalam hal anak menyusun pengetahuan dan terinspirasi oleh Montessori dalam hal kemerdekaan anak saat belajar. Ki Hajar Dewantara dalam mengkonsepkan pendidikan anak-anak terinspirasi oleh Montessori dalam hal kemerdekaan anak dan eksplorasi sensori. Juga terinspirasi oleh Frobel dalam hal bermain. Ki Hajar mengatakan kodrat anak adalah bermain sepanjang hari dan anak belajar lewat permainan.

Ki Hajar Dewantara adalah sosok pendidik yang berpendirian teguh. Meskipun terinspirasi oleh kedua tokoh pendidikan yang besar ini, Ki Hajar mengatakan meskipun dalam pendidikan anak Montessori memberikan kemerdekaan dan mengasah panca indera, namun aktivitasnya lebih menekankan eksperimen dan terasa kurang permainan. Sedangkan Frobel memasukan unsur permainan di dalam aktivitasnya. Ki Hajar mengatakan bahwa Indonesia sudah memiliki permainan tradisional yang mengasah panca-indera, kesenangan bermain dan keterampilan sekaligus seperti permainan dakon dan cublak-cublak suweng yang mengasah pancaindera, permainan dan keterampilan matematika serta perkiraan sekaligus.

Maka tidak perlu mengadopsi metode pendidikan luar secara bulat-bulat, namun disesuaikan dengan konteks masyarakat dan budaya setempat. Menurut Ki Hajar Dewantara hal inilah yang akan memerdekakan anak, yaitu ketika anak tahu kodratnya dan jelas identitas dirinya sebagai bangsa Indonesia. Sehingga konsep merdeka antara Ki Hajar Dewantara, Montessori dan Loris Malaguzzi memiliki perbedaan. Karena kemerdekaan menurut Ki Hajar Dewantara adalah bersifat nasionalisme sedangkan kemerdekaan konsep Montessori adalah kemerdekaan belajar, dan kemerdekaan Loris Malaguzzi adalah memiliki hak sebagai warga negara.

Ki Hajar Dewantara juga terinspirasi oleh pendidikan Antroposofis dari Rudolf Steiner atau yang saat ini dikenal sebagai Pendidikan Waldorf, yang mencetuskan Eurhytmy. Eurhytmy adalah sebuah konsep pendidikan etika dan estetika yang dapat membangun budipekerti. Ki Hajar Dewantara sependapat dengan Steiner, dia mengatakan bahwa kebudayaan Indonesia baik itu tari, pencak silat, pendidikan jasmani harus diajarkan kepada anak karena banyak manfaatnya.

Kesenian dan kegiatan fisik di dalam budaya Indonesia selain mendatangkan manfaat fisik seperti kesehatan dan ketangkasan, juga bermanfaat bagi panca indera seperti ketelitian, ketajaman, penglihatan yang awas, selain itu juga mendatangkan manfaat dalam etik seperti keteguhan hati, ketertiban serta manfaat estetis yaitu memperhalus tingkah laku. Ki Hajar Dewantara melihat aktivitas ini mengandung pendidikan etik dan estetik yang dapat mengasah budipekerti, dan Ki Hajar Dewantara menyebutnya "dari Kodrat kearah Adab".

Meskipun pada gambar 17 dapat dilihat antara Pendekatan Reggio Emilia dan pendidikan Ki Hajar Dewantara memiliki kesamaan seperti kurikulum harus disesuaikan dengan tempat mereka tinggal, tidak dapat dilepaskan dari masyarakatnya, membiasakan murid mencari pengetahuannya sendiri dan menggunakan pengetahuan untuk kepentingan bersama. Namun, dalam fokus utama kurikulumnya sangat berbeda, dimana Kurikulum Reggio Emilia berfokus pada praktik politik demokratis yaitu anak dapat mengeluarkan potensinya dan menyuarakan 100 bahasa anak. Serta berfokus pada ranah kognitif seperti proyek jangka panjang, fokus pada proses, anak menjadi peneliti, dan membangkitkan rasa ingin tahu anak. Sedangkan kurikulum dalam pendidikan Ki Hajar Dewantara fokusnya adalah pendidikan karakter dan pendidikan nasionalisme.

\section{SIMPULAN}

Pendekatan Reggio Emilia dengan kedelapan komponennya mampu menjawab empat tantangan kemampuan di abad ke-21. Adanya persamaan dan perbedaan sekaligus dari konsep Pendekatan Reggio Emilia dan Pendidikan Ki Hajar Dewantara, serta perbedaan teori etnoparental antara Italia dan Indonesia, tentu akan muncul tantangan tersendiri jika ingin 
menerapkan Pendekatan Reggio Emilia di Indonesia. Namun bukan bearti Pendekatan Reggio Emilia tidak dapat diterapkan di Indonesia. Seperti yang dikatakan oleh Ki Hajar Dewantara, bahwa kita harus terus berubah sesuai zaman dan seperti yang dikatakan oleh pendidik Reggio Emilia, bahwa terinspirasi adalah menyesuaikannya dengan kearifan lokal setempat.

\section{UCAPAN TERIMA KASIH}

Terimakasih kepada Tuhan Yang Maha Esa karena penyertaanNya sehingga penelitian ini dapat dilakukan. Terimakasih kepada pembimbing yang sudah memberikan masukan pada penelitian ini. Terimakasih pada semua pihak yang telah membantu sehingga penelitian ini dapat dipublikasikan. Terimakasih kepada para peneliti terdahulu yang menjadi sumber rujukan dalam penelitian ini.

\section{DAFTAR PUSTAKA}

Adu, J., \& Kissiedu, K. (2016). Exploring Childrens Communication Through Art in the Early Years: The Role of the Teacher. August, 424-435.

Akar, A., \& Gonen, M. (2015). Examination of The Effects of Reggio Emilia Based Projects on Preschool Children ' s Creative Thinking Skills. Elsevier, 186(312), 456-460. https://doi.org/10.1016/j.sbspro.2015.04.120

Amus, G. (2013). An alternative journal into forest kindergartens and the Reggio Emilia approach. University of Eastern Finland, 5-22.

Arnott, L., \& Grogan, D. (2016). Lessons from using iPads to understand young children ' s creativity. https://doi.org/10.1177/1463949116633347

Arseven, A. (2016). The Reggio Emilia approach and curriculum development process. International Journal of Academic Research, January 2014. https://doi.org/10.7813/20754124.2014/6-1/B.23

Astuti, O. F., \& Puji, H. (2017). The Creativity of Early Childhood Painting Through Media Waste in Islamic Center Kindergarten Brebes. 6(2), 2-6.

Baker, F. S. (2015). Reflections on the Reggio Emilia approach as inspiration for early childhood teacher education in Abu Dhabi , UAE. Routledge, 185(6), 982-995. https://doi.org/10.1080/03004430.2014.974036

Barnaby, B. (2016). From Theory to Practice : Critical Thinking as a Multifaceted Concept. JPAAP. https://doi.org/10.14297/jpaap.v4i3.209

Baroutsis, A., Kervin, L., Woods, A., \& Comber, B. (2019). Understanding children ' s perspectives of classroom writing practices through drawings. https://doi.org/10.1177/1463949117741743

Beavers, E., Orange, A., \& Kirkwood, D. (2017). Fostering critical and reflective thinking in an authentic learning situation. Journal of Early Childhood Teacher Education, 38(1), 3-18. https:// doi.org/10.1080/10901027.2016.1274693

Bell, S. (2010). Project-Based Learning for the 21st Century : Skills for the Future. Routledge, 39-43. https://doi.org/10.1080/00098650903505415

Birinci, C. M. (2018). Teacher in Reggio Emilia Approach: Educational Needs and Views. EURASIA, 14(1), 279-290. https://doi.org/10.12973/ejmste/79800

Bond, V. L. (2015). Sounds to Share: The State of Music Education in Three Reggio Emilia - Inspired North American Preschools. National Association for Music Education. https://doi.org/10.1177/0022429414555017

Boyd, D. (2019). The legacy café- the holistic benefit of reviving lost arts , crafts and traditional skills through an early childhood intergenerational sustainable skills project. Education 313, 0(0), 1-13. https:/ / doi.org/10.1080/03004279.2019.1603247

Boyd, D., \& Bath, C. (2017). Capturing Student Perspectives Through a' Reggio ' Lens. International Journal of Teaching and Learning in Higher Education, 29(2), 192-200.

Cahyani, N. B., Winata, W., \& Dewi, H. I. (2019). Open-Ended Game with Visual Art to Develop Creativity Culture in Early Childhood. 419(Icade 2019), 42-45. https://doi.org/10.2991/assehr.k.200321.011 
Cline, K. D., Gilb, M., \& Vaught, M. (2019). Honoring Children ' s Ways of Knowing : A Story of Trust and Transformation in a Kindergarten Classroom. 12, 77-90. https://doi.org/10.36510/learnland.v12i1.980

Cutcher, A. (2013). Art Spoken Here: Reggio Emilia for the Big Kids. IJADE, 3(2013), 318-330. https://doi.org/10.1111/j.1476-8070.2013.12028.x

Daly, L., \& Beloglovsky, M. (2019). Loose Parts 4 (Inspiring 21st Century Leraning). Redleaf Press.

Dev, D., Burton, A., Mcbride, B. A., Edwards, C., Garcia, A., Edwards, C. P., \& Garcia, A. S. (2019). An Innovative, Cross-Disciplinary Approach to Promoting Child Health: The Reggio Emilia Approach and the Ecological Approach to Family Style Dining Program An Innovative , Cross-Disciplinary Approach to Promoting Child Health: The Reggio Emilia Approac. University of Nebraska Lincoln. https://doi.org/10.1080/00094056.2019.1565811

Dewantara, K. H. (2013). Ki Hajar Dewantara. Bagian Pertama: Pendidikan (Pemikiran, Konsepsi, Keteladanan, Sikap Merdeka) (5th ed.). Penerbit Universitas Sarjanawiyata Taman Siswa (UST-Press) bekerjasama dengan Majelis Luhur Persatuan Tamansiswa.

Dodd-nufrio, A. T. (2011). Reggio Emilia , Maria Montessori , and John Dewey : Dispelling Teachers ' Misconceptions and Understanding Theoretical Foundations. Springer, 235-237. https:// doi.org/10.1007/s10643-011-0451-3

Duran, M. (2016). The effect of the inquiry-based learning approach on student ' s critical -thinking. Eurasia Journal of Mathematics, Science \& Technology Education, 12(12), 2887-2908. https://doi.org/10.12973/eurasia.2016.02311a

Edwards, C., \& Gandini, L. (2012). The Hundred Languages of Children (G. Forman (ed.)). Praeger.

Edwards, Carolyn P. (2003). "Fine Designs" from Italy: Montessori Education and the Reggio Approach. December.

Edwards, Carolyn P, \& Ren, L. (2016). Retrospective Review and Contemporary Development of the Reggio Emilia Early Childhood Educational System : An Interview with Carolyn Pope Edwards.

Edwards, Carolyn Pope, \& Gandini, L. (2018). THE REGGIO EMILIA APPROACH TO EARLY CHILDHOOD EDUCATION. In Routledge (pp. 365-378). https:// doi.org/10.4324/9781315562193-26

Efron, S. E., \& Ravid, R. (2019). Writing the literature review : a practical guide. The Guilford Press. Häkkinen, P., Järvelä, S., Mäkitalo-siegl, K., Ahonen, A., Näykki, P., \& Valtonen, T. (2016). Preparing teacher-students for twenty-first- century learning practices ( PREP 21 ): a framework for enhancing collaborative problem-solving and strategic learning skills. 0602(July). https://doi.org/10.1080/13540602.2016.1203772

Hanafi, Z. M. (2014). Implementasi Metode Sentra Dalam Pengembangan Kecerdasan Majemuk Anak Usia Dini.

Hanna, W. (2013). A Reggio-Inspired Music Atelier : Opening the Door Between Visual Arts and Music. Springer, 287-294. https:// doi.org/10.1007/s10643-013-0610-9

Harris, H. (2018). Parental Choice and Perceived Benefits of Reggio Emilia Inspired Programs. Walden University.

Harrison, L. J., \& Mcleod, S. (2009). Listening to children with communication impairment talking through their drawings.

Haryono, S. E., Wulandari, N. W., Eva, N., \& Anggraini, H. (2019). Critical Thinking Skills And Self Regulated Learning In The Learning Process In Early Childhood. Proceeding of International Conference of Psychology 2019, 92-96.

Helm, J. H. (2000). The Project Approach Catalog 3. In ERIC.

Hertzog, N. B. (2001). Reflections and Impressions from Reggio Emilia : " It ' s Not about Art!" ERIC, 4.

Hocevar, A., Kova, M., \& Štefanc, D. (2013). European Early Childhood Education Curriculum planning and the concept of participation in the Reggio Emilia pedagogical approach. December 2014, 37-41. https:/ / doi.org/10.1080/1350293X.2013.845437

Hong, S. B., Shaffer, L., \& Han, J. (2016). Reggio Emilia Inspired Learning Groups : Relationships , Communication, Cognition, and Play. Early Childhood Education Journal, July 2016. https://doi.org/10.1007/s10643-016-0811-0 
Kandari, A. M. Al. (2020). E-Task-Based Learning Approach to Enhancing 21st-Century Learning Outcomes. 13(1), 551-566. https://doi.org/10.29333/iji.2020.13136a

Kaufman, K. J. (2013). 21 Ways to 21st Century Skills: Why Students Need Them and Ideas for Practical Implementation. May 2015, 37-41. https:// doi.org/10.1080/00228958.2013.786594

Kewalramani, S. (2020). Children ' s Engineering Design Thinking Processes: The Magic of the ROBOTS and the Power of BLOCKS (Electronics ). 16(3). https://doi.org/10.29333/ejmste/113247

Knight, L. (2008). Communication and Transformation through Collaboration : rethinking drawing activities in early childhood. 9(4), 306-316. https://doi.org/10.2304/ciec.2008.9.4.306

Knight, L., Zollo, L., Mcardle, F., Cumming, T., Bone, J., Peterken, C., Li, L., Knight, L., Zollo, L., Mcardle, F., Cumming, T., \& Bone, J. (2016). Drawing out critical thinking: testing the methodological value of drawing collaboratively. European Early Childhood Education Research Journal, 1807(April). https:// doi.org/10.1080/1350293X.2016.1143270

Kostelnik, M. (2014). Developmentally appropriate curriculum best practices in early childhood education. In Pearson (5th ed.). Pearson.

Laar, E. Van, Deursen, A. J. A. M. Van, Dijk, J. A. G. M. Van, \& Haan, J. De. (2017). The relation between 21st-century skills and digital skills : A systematic literature review. Computers in Human Behavior, 72, 577-588. https://doi.org/10.1016/j.chb.2017.03.010

Lai, E. R. (2011). Collaboration: A Literature Review Research Report. June.

Latta, M. M., Hanson, K., Ragoonaden, K., Briggs, W., \& Tamalee Middleton. (2017). Accessing the Curricular Play of Critical and Creative Thinking. Canadian Journal of Education, 3(23), 191-218.

Leggett, N. (2013). Understanding the roles educators and children play as intentional teachers and intentional learners within the Early Years Learning Framework. Australian Journal of Early Childhood. https:// doi.org/10.1177/183693911303800406

Lindeman, K. W., \& Anderson, E. M. (2015). Using Block to Develop 21st century skills. March.

Lindsay, G. M. (2015). Reflections in the mirror of Reggio Emilia ' s soul: John Dewey ' s foundational influence on pedagogy in the Italian educational project. Early Childhood Education Journal, 43, 447-457. https://doi.org/10.1007/s10643-015-0692-7

Magta, M. (2013). Konsep Pendidikan Ki Hajar Dewantara pada Anak Usia Dini. Jurnal Pendidikan Usia Dini, 7 EDISI 2(11), 221-232.

Matei, C. S. (2018). Advocacy for the Study of Critical Thinking. Euromentor Journal Studies about Education, IX(1), 48-54.

Mcnally, S. A., \& Slutsky, R. (2016). Key elements of the Reggio Emilia approach and how they are interconnected to create the highly regarded system of early childhood education. Early Child Development and Care, 0(0), 1-13. https://doi.org/10.1080/03004430.2016.1197920

Miller, V. (2019). Creating the Third Teacher Through Participatory Learning Environment Design : Reggio Emilia Principles Support Student Wellbeing. Springer Singapore. https:// doi.org/10.1007/978-981-13-6092-3

Mitchiner, J., Batamula, C., Kite, B. J., Mitchiner, J., Batamula, C., \& Kite, B. J. (2018). Hundred Languages of Deaf Children: Exploring the Reggio Emilia Approach in Deaf Education Hundred Languages of Deaf Children: Exploring the Reggio Emilia Approach in Deaf Education. 163(3), 294-327. https:// doi.org/10.1353/aad.2018.0021

Muryanti, E., \& Herman, Y. (2017). Building Children ' s Critical Thinking by Puzzle Story Telling. 58, 147-151. https:// doi.org/10.2991/icece-16.2017.25

Nurjanah, N. E., \& Wahyuseptiana, Y. I. (2018). The Aplication Of Playing Based on Reggio Emilia's Approach to Stimulate Early Childhood Creativity. Jurnal UNS, 1(Snpd), 555-561. https://doi.org/10.20961/shes.v1i1.23600

Perren, S., Herrmann, S., Iljuschin, I., Frei, D., Körner, C., \& Sticca, F. (2017). Child-centred educational practice in different early education settings : Associations with professionals ' attitudes , self-efficacy, and professional background. 38, 137-148. https://doi.org/10.1016/j.ecresq.2016.07.001

Reggio Children. (2008). Children, Art, Artists The expressive language of children, the artistic languange of Alberto Burri. Reggio Children. 
Roberts holmes, G. (2017). Loris Malaguzzi , Reggio Emilia and Democratic Alternatives to Early Childhood Education Assessment. FORUM, 59(2), 159-168. https://doi.org/10.15730/forum.2017.59.2.159

Rowe, M. L., Salo, V. C., \& Rubin, K. (2018). Toward Creativity Do Theatrical Experiences Improve Pretend Play and Cooperation among Preschoolers? 10(2), 193-207.

Santín, M. F., \& Torruella, M. F. (2017). Reggio Emilia: An Essential Tool to Develop Critical Thinking in Early Childhood. Journal of New Approach in Education Research, 6(1), 50-56. https://doi.org/10.7821/naer.2017.1.207

Smith, S. C. (2014). Parental Engagement in a Reggio Emilia - inspired Head Start Program. ERCP.

Stegelin, D. A. (2003). Application of the Reggio Emilia Approach to Early Childhood Science Curriculum. Early Childhood Education Journal, 2003. https://doi.org/10.1023/A:1022013905793

Stremmel, A. J. (2012). A Situated Framework The Reggio Experience. In Curriculum in Early Childhood Education (pp. 133-145). Routledge.

Sundararajan, N., Adesope, O., \& Cavagnetto, A. (2018). The Process of Collaborative Concept Mapping in Kindergarten and the Effect on Critical Thinking Skills. Journal of STEM Education, March, 5-13.

Vatalaro, A., Szente, J., \& Levin, J. (2015). Transformative learning of pre-Service teachers during study abroad in Reggio Emilia , Italy : A case study. Journal of Scholarship of Teaching and Learning, 15(2), 42-55. https://doi.org/10.14434/josotl.v15i2.12911

Weber, M. (2019). The Importance of Collaboration Within Project- Based Learning in a Kindergarten Teacher Classroom.

Weinstein, S. (2017). Scaffolding to Promote Critical Thinking and Learner Autonomy Among PreService Education Students. 4(1), 69-87. https://doi.org/10.5296/jet.v4i1.9871

Wien, C. A., Guyevskey, V., \& Berdoussis, N. (2011). Learning to Document in Reggio-inspired Education. ECRP.

Wright, S. (2016). The art of voice : The voice of art - understanding children ' s graphic- narrativeenactive communication. ResearchGate, January 2014.

Yates, E., \& Twigg, E. (2017). Developing creativity in early childhood studies students. https://doi.org/10.1016/j.tsc.2016.11.001

Zulkarnaen, R. H., Setiawan, W., Rusdiana, D., \& Muslim, M. (2018). Smart city design in learning science to grow 21 st century skills of elementary school student. https://doi.org/10.1088/1742-6596/1157/2/022021 


\section{Lampiran}

\section{Daftar Artikel Dan Buku Yang Dianalisa}

\begin{tabular}{|c|c|}
\hline No & Judul Penelitian \\
\hline 1. & $\begin{array}{l}\text { Teacher in Reggio Emilia Approach: Educational Needs and View } \\
\text { (Birinci, 2018) }\end{array}$ \\
\hline 2. & $\begin{array}{l}\text { Loris Malaguzzi, Reggio Emilia and Democratic Alternatives to Early } \\
\text { Childhood Education Assessment } \\
\text { (Roberts holmes, 2017) }\end{array}$ \\
\hline 3. & $\begin{array}{l}\text { Art Spoken Here: Reggio Emilia for the Big Kids } \\
\text { (Cutcher, 2013) }\end{array}$ \\
\hline 4. & $\begin{array}{l}\text { Reflection and Impression from Reggio Emilia: It's Not About Art! } \\
\text { (Hertzog, 2001) }\end{array}$ \\
\hline 5. & $\begin{array}{l}\text { Parental Choice and Perceived Benefits of Reggio Emilia Inspired } \\
\text { Program } \\
\text { (Harris, 2018) }\end{array}$ \\
\hline 6. & $\begin{array}{l}\text { Reggio Emilia: An Esessential Tool to Develop Chritical Thinking in } \\
\text { Early Childhood } \\
\text { (Santín \& Torruella, 2017) }\end{array}$ \\
\hline
\end{tabular}

7. Reggio Emilia, Maria Montessori, and John Dewey: Dispelling Teachers' Misconception and Understanding Theoretical Foundation (Dodd-nufrio, 2011)

8. Key elements of the Reggio Emilia approach and how they are interconnected to created the highly regarded system of early childhood education

(Mcnally \& Slutsky, 2016)

9. "Fine Design" from Italy: Montessori Education and Reggio Emilia Approach"

(Carolyn P Edwards, 2003)

10. Creating the Third Teacher Through Participatory Learning Environment Design: Reggio Emilia Principles Support Student Wellbeing

(Miller, 2019)

11. "Hundred Languange of Deaf Children: Exploring The Reggio Emilia Approach in Deaf Education" (Mitchiner et al., 2018).

12. "Transformative Learning of Pre-service Teachers During Study Aboard to Reggio Emilia, Italy: A case study"

(Vatalaro et al., 2015)

13. An Innovative, Cross Disciplinary Approach to Promoting Children Health: The Reggio Emilia Approach and the Ecological Approach to Family Style Dinning Program

(Dev et al., 2019)

14. The Application of Playing Based on Reggio's Emilia Approach to Stimulate Early Childhood Creativity (Nurjanah \& Wahyuseptiana, 2018)

15. Honoring Childrens Way's of Knowing: A Story of Trust and Transformation in a Kindergarden Classroom (Cline et al., 2019)

16. Children, Art, Artists The expressive language of children, the artistic Reggio Children language of Alberto Burri (Reggio Children, 2008) 


\begin{tabular}{lll}
\hline No & Judul Penelitian & Jurnal/Penerbit \\
\hline 17. & Capturing Student Perspectives Through a' Reggio' Lens & International \\
& (Boyd \& Bath, 2017) & Journal of \\
& & Teaching and \\
& & Learning in \\
18. & A Situated Framework: The Reggio Experience & Higher Education \\
\end{tabular}

(Stremmel, 2012)

19. Curriculum planning and the concept of participation in the Reggio Routledge

Emilia pedagogical approach Andreja TaylorE

(Hocevar et al., 2013) Francis Group

20. Application of the Reggio Emilia Approach to Early Childhood Science Early Childhood

Curriculum

Education Journal

(Stegelin, 2003)

21. Retrospective Review and Contemporary Development of the Reggio University of

Emilia Early Childhood Educational System : An Interview with Nebraska-Lincoln

Carolyn Pope Edwards

(Carolyn P Edwards \& Ren, 2016)

22. The Reggio Emilia Approach to Early Childhood Education Routledge

(Carolyn Pope Edwards \& Gandini, 2018)

23. Reflections on the Reggio Emilia approach as inspiration for early Routledge

childhood teacher education in Abu Dhabi, UAE

(Baker, 2015)

24. Reggio Emilia Inspired Learning Groups : Relationships, Springer

Communication, Cognition, and Play

(Hong et al., 2016)

25. A Reggio-Inspired Music Atelier : Opening the Door Between Visual Springer

Arts and Music

(Hanna, 2013)

26. An Alternative Journal into Forest Kindergartens and the Reggio Emilia Approach

(Amus, 2013)

27. Learning to Document in Reggio-inspired Education

(Wien et al., 2011)

28. Examination of The Effects of Reggio Emilia Based Projects on Preschool Elsevier

Children's Creative Thinking Skills

(Akar \& Gonen, 2015)

29. Sounds to Share: The State of Music Education in Three Reggio Emilia

- Inspired North American Preschools

(Bond, 2015)

30. The Reggio Emilia approach and curriculum development process

(Arseven, 2016)

University of

Eastern Finland

ECRP

SAGE

International

Journal of

Academic

Research

31. Understanding the roles educators and children play as intentional

Australian

teachers and intentional learners within the Early Years Learning

Framework

Journal of Early

Childhood

(Leggett, 2013)

32. Reflections in the mirror of Reggio Emilia' s soul : John Dewey 's foundational influence on pedagogy in the Italian educational project (Lindsay, 2015)

33. Parental Engagement in a Reggio Emilia-inspired Head Start Program ERCP (Smith, 2014) 
DOI: 10.31004 /obsesi.v6i1.1228

\begin{tabular}{ll}
\hline No & Judul Penelitian \\
\hline 34. & The Hundred Languages of Children \\
(C. Edwards \& Gandini, 2012) \\
35. 21 Ways to 21st Century Skills: Why Students Need Them and Ideas for \\
Practical Implementation \\
(Kaufman, 2013) \\
36. Preparing teacher-students for twenty-first- century learning practices \\
(PREP 21 ): a framework for enhancing collaborative problem-solving \\
and strategic learning skills \\
(Häkkinen et al., 2016) \\
The relation between 21st-century skills and digital skills : A systematic \\
literature review \\
(Laar et al., 2017) \\
38ing Blocks to Develop 21st Century Skills \\
(Lindeman \& Anderson, 2015) \\
The Creativity of Early Childhood Painting Through Media Waste in \\
Islamic Center Kindergarten Brebes \\
(Astuti \& Puji, 2017) \\
Open-Ended Game with Visual Art to Develop Creativity Culture in \\
Early Childhood \\
(Cahyani et al., 2019) \\
The legacy café- the holistic benefit of reviving lost arts, crafts and \\
traditional skills through an early childhood intergenerational \\
sustainable skills project \\
(Helm, 2000) \\
Developing creativity in early childhood studies students \\
(Yates \& Twigg, 2017) \\
Toward Creativity Do Theatrical Experiences Improve Pretend Play and \\
Cooperation among Preschoolers ? \\
(Rowe et al., 2018)
\end{tabular}

44. The process of collaborative concept mapping in Kindergarten and the effect on critical thinking skill.

Jurnal/Penerbit

PRAEGER

Kappa Delta Pi

Record

Routledge

Elsevier

NAEYC

BELIA

\section{ATLANTIS \\ PRESS}

Routledge

Elsevier

American Journal of Play

Journal of STEM

Education (Sundararajan et al., 2018)

45. Scaffolding to Promote Critical Thinking and Learner Autonomy Among Pre-Service Education Students

(Weinstein, 2017)

Journal

Education

Trainning

46. Fostering critical and reflective thinking in an authentic learning

TaylorEFrancis situation

(Beavers et al., 2017)

47. Drawing out critical thinking : testing the methodological value of Routledge drawing collaboratively

(Knight et al., 2016)

48. Advocacy for the Study of Critical Thinking

(Matei, 2018)

49. Accessing the Curricular Play of Critical and Creative Thinking (Latta et al., 2017)

50. Critical Thinking Skills And Self Regulated Learning In The Learning Process In Early Childhood

(Haryono et al., 2019)

Euromentor

Journal

Canadian Journal of Education

Proceeding of

International

Conference of

Psychology

51. From Theory to Practice: Critical Thinking as a Multifaceted Concept JPAAP (Barnaby, 2016) 


\begin{tabular}{ll}
\hline No & Judul Penelitian \\
\hline 52. & $\begin{array}{l}\text { The effect of the inquiry-based learning approach on student's s critical } \\
\text {-thinking } \\
\text { (Duran, 2016) }\end{array}$ \\
53. Communication and Transformation through Collaboration : rethinking \\
$\begin{array}{l}\text { drawing activities in early childhood } \\
\text { (Knight, 2008) }\end{array}$
\end{tabular}

54. Exploring Childrens Communication Through Art in the Early Years: The Role of the Teacher

(Adu \& Kissiedu, 2016)

55. Listening to children with communication impairment talking through their drawings

(Harrison \& Mcleod, 2009)

56. The art of voice: The voice of art - understanding children's graphicnarrative-enactive communication

(Wright, 2016)

57. Understanding children' s perspectives of classroom writing practices through drawings

(Baroutsis et al., 2019)

58. Collaboration: A Literature Review Research Report

(Lai, 2011)

59. Kolaborasi Guru Kelas dan Tahfidz dalam Meningkatkan Konsep Diri Peserta Didik Kelas Atas Penghafal Al-Qur'an di SDIT BAIK (Hidayati \& Hidayat, 2018)

60. Technology enhanced collaborative learning using a project-based learning management system

(O'Sullivan et al., 2017)

61. Ki Hajar Dewantara. Bagian Pertama: Pendidikan (Pemikiran, Konsepsi, Keteladanan, Sikap Merdeka)

(Dewantara, 2013)

62. (Shwalb et al., 2010)

Maternal Beliefs, Images, and Metaphors of Child Development in the United States, Korea, Indonesia, and Japan

63. Pengembangan Model Etnoparenting Indonesia pada

Pengasuhan Anak

(Rachmawati, 2020)

64. Parental Ethnotheories and Family Routines: A Comparison Between

Italian and Ecuadorian Mothers in Italian Context

(Rebora \& Rania, 2017)

65. Parental ethnotheories of children's learning

(Harkness et al., 2009)
Jurnal/Penerbit

Eurasia Journal of

Mathematics,

Science $\mathcal{E}$

Technology

Education,

Contemporary

Issues in Early

Childhood

Proceedings of

INCEDI 2016

Conference

Journal of

Earlychildhood

Research

ResearchGate

SAGE

PEARSON

Islamic Teacher

Journal

International

Journal of

Technology

Enhanced

Learning

Research and

Clinical Center

for Child

Development:

Annual Report

Obsesi (Jurnal

Pendidikan

Anak Usia Dini)

Nova Publisher 